\title{
近代大津の「遊覧都市」建設と都市計画 湖岸埋立と湖岸逍遙道路整備を中心に一
}

\author{
山口 敬太 $1 \cdot$ 田中 倫希 2 ・川崎 雅史 3 \\ 1正会員 京都大学大学院助教 工学研究科（ $=615-8540$ 京都府京都市西京区京都大学桂C1） \\ E-mail: yamaguchi.keita.8m@kyoto-u.ac.jp \\ 2非会員 エム・アール・アイリサーチアソシエイツ株式会社（†101-0047 東京都千代田区内神田1-13-1） \\ E-mail: m-tanaka@mri-ra.co.jp \\ 3正会員 京都大学大学院教授 工学研究科（干615-8540 京都府京都市西京区京都大学桂C1） \\ E-mail: kawasaki.masashi.7s@kyoto-u.ac.jp
}

\begin{abstract}
本研究は, 戦前の大津における都市計画街路と湖岸埋立及び遊覧施設計画の内容と策定意図, 実現過程 を明らかにし，これらを通じて近代大津の都市建設の理念，実現の手段と主体のはたらきを明らかにする ものである. 大津では明治末年以降, 市会を中心に湖岸埋立・道路整備構想が数度立案され，昭和初期に は琵琶湖の風致整備を基軸とした近代的「遊覧都市」の建設という理念が確立し，このもとに都市計画街 路網・埋立計画や遊覽施設計画が策定された。これらの計画は名勝地の連絡による遊覧交通系統の充実と, 遊覧施設や湖岸の風致の整備を意図したものであった，湖岸埋立と逍遙道路は公有地の売却益による事業 収入をもとに戦前から戦後にかけて実現した。これは市，県の遊覽都市建設という理念の共有に基づいた 長期にわたる協働的推進によるものであった.
\end{abstract}

Key Words : city planning, tourism development, scenic promenade, lake reclamation, Lake Biwa

\section{1. はじめに}

\section{(1) 研究の背景と目的}

本研究は, 1930 年代の大津市において「遊覧都市」 のビジョンに基づいて策定された都市計画街路網と湖岸 埋立計画，および遊覧施設計画について，その具体的内 容と計画策定意図，さらには湖岸埋立の実現過程を明ら かにするものである．近代大津の「遊覽都市」という都 市建設の理念，実現の手段，主体のはたらきを明らかに することを通じて，大津の水辺空間形成の起源を探る.

1920 年代以降の日本では鉄道や汽船などの交通網の 発達に伴い，観光は産業としても，また都市施策として も重要な位置を占めるようになった，たとえば京都では， 積極的な外客誘致や，博覧会や記念祭の開催を通じて観 光振興に努めていたが，1918 年頃から都市の繁栄策と して重視されはじめ，馬淵市長（1921 年就任），安田 市長（1925 年就任）は遊覧都市化の方針を掲げ，観光 を重視した都市施策を進めたことが知られる ${ }^{1)}$. 全国的 には 1930 年代に鉄道省が推進した国策としての「国際 観光政策」を背景に, 各地で観光施策が推進された. 大津においても京都に近接した地理条件，琵琶湖湖畔
という環境，また歴史資源の豊富さから観光が重要視さ れ，特に 1930 年代の琵琶湖ホテル（1934 年）建設の前 後には「遊覧都市」の建設が市是とされて，積極的に遊 覧系統の充実と琵琶湖の風致整備が進められた。なかで も大津では国際リゾート開発と旧都市計画法下の都市計 画街路・埋立計画の策定の時期が重なるという歴史的に も特異な状況がみられ，これにより都市計画に観光振興 の色彩が色濃くあらわれることとなった。一方，大津市 は平坦地に乏しく狭長な地勢であり，かつ人口稠密であ ったため，近代的施設の整備や新たな開発は至難であっ た．昭和初期には，交通問題の解消および都市施設の用 地確保は喫緊の課題であったが，同時に観光振興の側面 からも京都市内からの自動車によるアクセスが考慮され， 道路を中心とする広域的な遊覧系統の確立が期待されて いた。 これらの問題を解決するための手段が，1932 年 に都市計画決定された湖岸道路及び湖岸埋立であった。

本論各章では，大津市における「遊覧都市」の建設構 想 (2 章) , 明治以後の埋立・道路計画の変遷にみる遊 覽都市構想の形成過程（3 章），都市計画街路網計画及 び湖岸埋立計画の策定過程と計画意図（4-5 章），遊覧 施設整備計画の策定（6 章），都市計画湖岸埋立及び道 
路の実現過程（7 章）について論じる.これらの考察を 通じて, 戦前の大津の都市建設および風致整備の理念と, 実現の手段および関係主体のはたらきを明らかにする.

\section{(2) 研究の位置づけ}

戦前の大津市の都市計画に関する先行研究として市史 や砂本の研究がある. 大津市史は 1930 年代の都市計画 の策定について，大津市が「レーク・サイド・シチー」 としての条件と歴史的文化財の活用をもって，近代都市 に必要な道路と街路樹をはじめ, 湖岸の埋め立て, 水道 などの都市施設の充実を図ったものであったとする ${ }^{2}$.

また，大津市が 1933 (昭和 8) 年の市町村合併以降に観 光施設の充実を図り, 水泳場や公園の新設, 河岸の美化 や観光客への案内の充実などに努めたことも指摘する ${ }^{3}$.

一方，砂本は外客誘致のための国際観光政策としての 国際リゾート地開発(1)という観点から，1934（昭和 9） 年に竣工した琵琶湖ホテルの建設経緯を明らかにし，あ わせて琵琶湖ホテルを中心とする湖畔逍遙道路や山中越 ドライブウエーの整備構想案を新聞記事をもとに明らか にするなど，1930 年以降の大津市の遊覧都市建設構想 の一端を示した ${ }^{4}$.

しかしこれらの先行研究も, 大津の「遊覧都市」構想 の内実やその形成経緯, 計画の具体的内容やその計画意 図を十分に明らかにするものではない，その理由の一つ は, これらの研究が戦前の都市計画関係の行政史料を資 料として用いていないことにある(2). 本研究では，以上 の研究成果を基礎としながら, 戦前の都市計画関係史料 を新たに一次史料として用いて，策定時の都市計画の具 体的内容や策定過程，計画意図の詳細を明らかにする.

一方，戦後の都市建設については市史がその詳細を明 らかにしている。 その成果の概要は以下の通りである. 昭和 24 年に就任した大津市長・佐治誠吉 (1949-1952 年 在任）は「観光大津」を合言葉として，湖岸道路をはじ めとする観光道路の建設や公園整備などの都市再建に努 めた.この方針観光都市の確立をかかげた上原茂次市 長（1952-1964 年在任）においても引き継がれて強力に 推進された 5). 戦前に策定された都市計画が実現期を迎 え, 紺屋関や浜大津の湖岸道路は 1949 （昭和 24）年以 降順次進められ, 湖岸埋立についても特に 1960（昭和 35）年にかけて着々と実現し, 浜大津の整備が進められ た の. 大津における近代的都市の建設上，重要な位置づ けを有していた湖岸埋立事業ならびに湖岸道路は, 戦後 に規模をさらに拡大させながら, 昭和 40 年代前半まで に概ね実現した。造成された湖岸の埋立地は, 県や市の 諸施設や，市内の道路拡張等にともなう代替地として提 供するために用いられた 》。. 大津市における都市計画関 係の年表（表-1），および昭和 47 年までの湖岸埋立の 範囲 8) (図-1) を示す.
前述した戦後大津市の「近代的観光都市」の確立は, 戦後の歴代大津市長が一貫して掲げた都市構想であった. これが戦前の都市計画策定時の構想を引き継いだもので あるということは市史では概括的な指摘にとどまってい る. 大津における都市建設事業の大部分は戦後に実施さ れたものであるが，それらの計画策定は戦前に遡るため, 大津の都市形成とその背景を正確に理解寸るためには, 戦前の都市計画の計画意図を明らかにする必要がある.

以上をふまえた上で, 本研究では戦後大津の都市形成 の起源と位置付けられる 1920 年代以降の大津市の「遊 覧都市」計画の内実と, その後の経緯を明らかにし， あ わせて戦前から戦後にかけての計画理念の連続性を論じ る. 本研究で用いた資料は, 都市計画滋賀地方委員会資 料（議事録や参考資料，図面類等）を含む行政史料(3), 大津市会会議録，雑誌記事，新聞（主として大阪朝日新 聞滋賀版）等である（図-2）。都市計画地方委員会資料 は先行研究では用いられておらず, 本稿が初出となる.

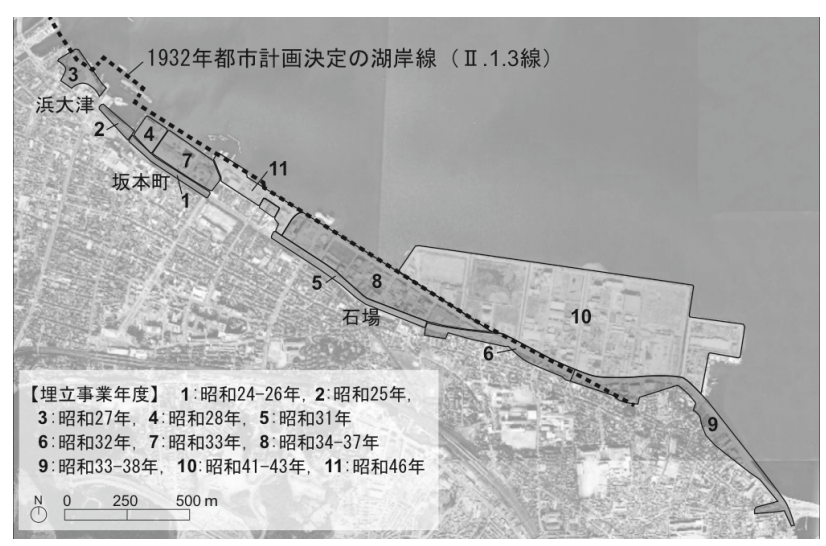

図-1 埋立範囲とその変遷

(『家族の一世紀』（1998）所収の埋立变遷図をもとに作成）

表-1 大津市の湖岸埋立と関連する都市計画の年表

\begin{tabular}{|c|c|}
\hline 年 & 大津市の都市計画に関する事項 \\
\hline 1913 & 太湖汽船による埋立事業が完了 \\
\hline 1925 & $\begin{array}{l}\text { 県・市・商工会議所による埋立会社が濱大津埋立計画を発表 } \\
\text { 柳力崎に公衆水泳場開設 }\end{array}$ \\
\hline 1927 & 大津市が都市計画法による「都市計画指定都市」に決定 \\
\hline 1929 & 大津都市計画区域の決定 \\
\hline 1932 & $\begin{array}{l}\text { 大津都市計画街路網・埋立の内務省による認可 } \\
\text { 大津市と滋賀村が合併 }\end{array}$ \\
\hline 1933 & $\begin{array}{l}\text { 大津市と膳所町，石山町が合併 } \\
\text { 京津国道開通 }\end{array}$ \\
\hline 1934 & 大津市長 : 市会に粟津湖岸埋立計画を提出 \\
\hline 1934 & $\begin{array}{l}\text { 琵琶湖ホテル開業 } \\
\text { 山中越ドライブウエイ (大津市錦織-山中間) が開通 }\end{array}$ \\
\hline 1935 & 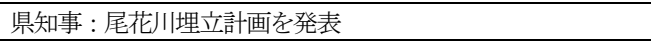 \\
\hline 1936 & 膳所湖岸埋立計画が大津市会で可決, 埋立開始（粟津,-1942） \\
\hline 1937 & 大津湖岸埋立開始 (尾花川,-1942) \\
\hline 1949 & 湖岸道路及び埋立（浜大津-馬場一丁目,-1957） \\
\hline 1958 & $\begin{array}{l}\text { 湖岸道路及び埋立（馬場一丁目-近江大橋,-1964) } \\
\text { 第一次湖岸埋立（浜大津-打出浜,-1963） }\end{array}$ \\
\hline 1963 & 戦前計画分の埋立事業完了 \\
\hline 1966 & 第二次湖岸埋立（におの浜-由美浜,-1968） \\
\hline 1967 & 湖岸道路完成 \\
\hline
\end{tabular}

(参考文献 : 『新修大津市史 第六巻』, 『家族の一世紀』) 

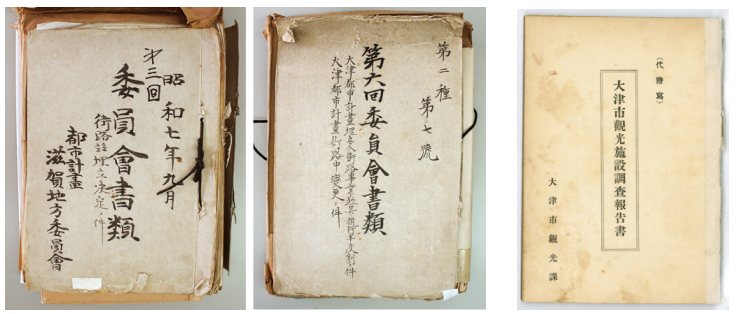

図-2 都市計画滋賀地方委員会書類（滋賀県県政史料室蔵） と『大津市観光施設調査報告書』（1933）

\section{(3) 考察の視点}

先行研究の成果をふまえて，本研究では近代の大津に おける都市建設および風致整備について, 理念, 手段, 関係主体のはたらき，の三つの論点に重きを置いて論じ る.

第一の論点は「理念」である. 大津の都市建設はいか なる都市像に根ざして進められたか，という問いに対し て，都市経営策としての「遊覧都市」構想の内実と，そ の都市計画における位置付けを明らかにする。なかでも 湖岸逍遙道路の実現を通じた公共空間形成のねらいを明 らかにする．また，長期にわたる事業推進のなかでの計 画理念の連続性について考察する.

第二の論点は「手段」である。すなわち「遊覧都市」 の建設の手段としての旧都市計画法の活用実態を中心に 明らかにする。なかでも遊覧都市の実現のために都市計 画決定された街路網計画の計画意図と，景観価值の創出 を目指した湖岸道路および埋立の設計内容，さらには湖 岸埋立の事業化のための事業予算創出の実態を明らかに する.

第三の論点は「主体」である，近代大津における都市 建設計画の策定や事業化において地域主体（議会，市民） と県や国，さらには都市計画技術者が果たした役割，各 主体の意図，さらには主体間の協働の実態を明らかにす る. 特に街路と埋立計画の策定を担った塩原三郎技師の 関与の実態と，塩原の計画意図について明らかにする. また，都市計画案立案以前からの都市構想の変遷に加え て，各主体の関与の変遷を明らかにし，都市にかかわる 主体の連続性について考察する.

\section{2. 大津市における「遊覧都市」の建設構想}

\section{(1)「遊覧都市」という都市像}

最初に本研究の重要なキーワードである大津市の「遊 覧都市」の構想について整理しておく．大津市が「遊覧 都市」の建設構想を明確にし，さかんに唱道するように なるのは 1930 年代初め以降である．明治大正期におい ては鉄道と汽船による観光が主流であり(4), 9), 10)，その基 点として浜大津港や紺屋関港がさかんに利用された。
1920 年代以降，琵琶湖協会の発足（1925 年），昭和天 皇の即位大礼（1928 年）を経て観光の大衆化が進み, とりわけ 1930 年の国際観光局の設置以降，大津では国 際リゾート地開発運動が急速に推進され，1934 年の琵 琶湖ホテル開業に至った。このとき大津では，都市計画 の策定（1929 年に都市計画区域決定）が同時平行して 進められており，1932 年に湖岸道路を含む都市計画街 路網及び湖岸埋立計画が決定したほか, 京都-大津間を 結ぶ京津国道の開通（1933 年）や山中越ドライブウエ 一の開通（1934 年）など，道路を中心とする観光開発 が急速に進められた。

大津市における都市計画指定への動きは，1927（昭和 2）年 9 月の大津市会における都市計画指定を促す建議 が直接の契機となる ${ }^{11)}$. 大津市長・奥野英太郎は都市計 画の必要性として, 都市の急激の発展膨張に対する権威 ある根本計画を策定する必要があるとした。ここに「遊 覧都市」の建設，具体的には山手の区画整理，市内の道 路網の整備，湖岸埋立の是非等を含む「根本計画」の必 要等が主張された(5)。市会での議論を受けて大阪朝日新 聞は「大大津市建設の理想，遊覧都市としての市是を確 立」し，その上で「商工都市的施設をも按配する」こと を求めた ${ }^{12)}$. 以後，大津市の将来像は「遊覧都市」とい う言葉に表され，大津市会での議論や新聞紙面上に度々 登場することとなる( ${ }^{(6)}$ 「遊覧都市」への具体的な期待 の内容は次章で示すが，遊覧道路やホテル・旅館，各種 娛楽施設の整備が期待されていた.

\section{（2）新大津市の発足と「遊覧都市」の建設構想}

大津市の「遊覧都市」建設構想は，1933（昭和 8）年 以降の周辺町村との合併の議論のなかでとりわけ明確に 主張された. 大津市は滋賀村との合併，膳所石山両町と の解消合併を行い，1933年 4 月に新大津市を発足させた が，同年 2 月 8 日の合併懇談会において，新大津市の市 長職務管掌となる滋賀県内務部長・三樹樹三が，一大遊 覧都市の建設ならびに山荘都市の建設のための都市計画 遂行の必要性を訴えた ${ }^{13)}$ ，三樹は「この地方をして日本 の遊覧都市否世界の観光都市としての本領を発揮せしめ なければならぬ $(\cdots)$ 此事を措いてこの地方が大発展を 遂げる方法は無い 遊覧都市としての発展策以外に當地 方の発展策は有り得ない」と，遊覧都市としての発展策 を不可欠なものとして強く主張した.

同じく，合併問題に関する滋賀県知事・伊藤武彦の声 明書には，各自治体の負担軽減や財政の強化，生活上の 各種便益のほ力，都市計画事業の実施や遊覧都市の建設 が挙げられた．都市計画事業の遂行，特に街路網計画と 湖岸埋立計画には莫大な費用がかかり，小さい町村では 実施が困難であったため，その実現のために市町村合併 の必要性が唱えられていた，実際に，県知事が内務大臣 
へ提出した禀請「大津市他ニヶ町习廃シ新二滋賀大津市 习置クノ義二付禀請」には，街路網及埋立計画の実施， その他の都市重要施設や遊覧施設の実現のためには合併 が必要不可欠であることが強調されていた ${ }^{14)}$.また，こ の合併条件には道路改修や公園やホテル（石山）等の遊 覧施設整備も定められた。

1933 （昭和 8）年 4 月 1 日に大津市長職務管掌となっ た三樹樹三は，新大津市建設に関する声明書「新大津市 の使命」を県下各新聞紙上で発表した. 声明文の一部を 以下に抜粋する.

「新市に在つては坂本方面より石山，瀬田に亘る一円の地 域に総合的に遊覧施設の完備を図り真に大遊覧都市たるの 実を備へしめ内外の観光客に十分の満足を与へ同時に土地 の発展を期せむとするのであります、いまや琵琶湖周遊道 路も完成せんとするの際湖南一帯の遊覧道路を更に完全な るものと為し西に日吉神社, 延暦寺, 三井寺の霊域に接し て最近しばらく具体化せむとしつつある滋賀神宮が造営せ られ，南に建部神社，石山寺，岩間寺，立木観音等の名所 に隣して目下着々計画を進めつつある石山遊園地が実現し， 之に配する優美なる国際ホテル，至宝を集めたる博物館，

宏大なる競漕観覧場等を以て本市の面目は一新し瑞西のゼ ネヴアと並んで内外観光遊覧客の憧憬の地となる ${ }^{15}$ 」

この声明において三樹は，大津市の「使命」として二 つ挙げた. 第一には「近代都市に適はしき各種の施設を 完成する」こと，すなわち交通，衛生保健，教育，社会 事業，経済等の完備を実現することを挙げた．第二の使 命には「湖南名勝の総合的遊覧施設を完備する」ことを 挙げた. 具体的には坂本方面より, 石山, 瀬田にわたり, 遊覧道路を含めた総合的な遊覧施設の完備を図り，内外 の観光客を満足させ，瑞西のジュネーブと並ぶ観光都市 としての発展を目指すといったビジョンが明確に示され た.

以上の様に，国際リゾート地開発運動と都市計画案の 策定を同時に進めていた 1930 年代前半の大津において,

「遊覧都市」の建設は市の最重要の使命として掲げられ た. 以後，この大津市の市町村合併による拡大を契機と して，県市が一体となって遊覧都市建設というコンセプ 卜を明確に打ち出し，積極的に推進していく．その具体 的計画の内容は後述する.

\section{3. 近代大津における遊覧都市構想の形成過程}

本章では湖岸埋立を中心とする近代大津の都市整備案 の変遷を示し，「遊覧都市」構想の形成過程を明らかに する. 都市計画決定以前の湖岸埋立計画を整理したもの が表-2 である. 以下，時系列で各時代の湖岸埋立・道 路計画の内容を示す.

\section{（1） 大津湖岸における埋立 $\cdot$ 道路計画の嚆矢}

a) 浜大津における湖南汽船による湖岸埋立 (1910)

浜大津における湖岸埋立とその風致整備については, 管見の限り 1913 （大正 2）年から湖南汽船株式会社が, 湖南町地先（図-1 の 1 と 5 の間）において行った 3,455 坪の埋立事業がその嗃矢である. 本事業の詳細について はこれまで明らかにされていない.

湖南汽船は 1909 (明治 42）年 12 月に滋賀県に対して, 従来の港湾の規模が狭小なことによる営業上の不便を理 由に，会社の工費負担による紺屋関港改築の出願を行っ た. 本出願は県知事と内務省土木局長による許可を経て 1912 （大正元）年 10 月に認可され，滋賀県令第 48 号 「水面埋立并使用規則」（1891 年制定）に依り，埋立 工事が進められた 16)。工事竣工前の 1913 年 9 月 8 日に は湖南汽船専務・谷口賢次郎より神戸鉄道管理局長に宛

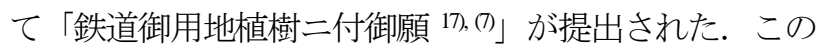
出願は，埋立地が大津市湖岸中「風景絶勝の地」であり

「公衆の娛楽場」となる事から, 湖岸に松桜楓柳等の風 致木数十株を植栽する旨の許可を求めたものである．植 樹の手入れ一切は湖南汽船が行うこととし，鉄道管理局 の許可を得て，湖南汽船は植栽を行った ${ }^{18)}$. 大津を中心 として琵琶湖での遊覧事業を経営していた民間会社の手 によって，護岸の景観整備の第一歩が進められた.

b) 大津市会による湖岸埋立と逍遙道路の構想（1911）

浜大津において大規模な湖岸埋立が具体化したのは,

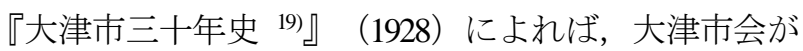
1911 （明治 43）年に大阪の河野天瑞に設計を依頼した 埋立設計が最初である。河野が立案した石場-坂本町間 の 34,400坪（約 11.3 万 $\mathrm{m}^{2}$ ，工費 30 万円）の埋立計画は， 市長から市参事会に諮問されたが，大津市長・西川太治

表-2 浜大津における湖岸埋立計画の変遷

\begin{tabular}{|c|c|c|c|c|}
\hline & 年 & 計画主体 & $\begin{array}{c}\text { 埋立区域 } \\
\text { 面積 }\end{array}$ & 主な整備内容(一部) \\
\hline 1 & \begin{tabular}{|l}
1910 \\
明治 43
\end{tabular} & $\begin{array}{l}\text { 大津市長(西川) } \\
\text { 市長が市参事会 } \\
\text { に諮問 }\end{array}$ & $\begin{array}{l}\text { 坂本町-石場 } \\
\text { /約 } 11.3 \text { 万 } \mathrm{m}^{2}\end{array}$ & $\begin{array}{l}\text { 紺屋関港改修を契機とする湖 } \\
\text { 岸埋立, 工費 } 30 \text { 万円 }\end{array}$ \\
\hline 2 & $\begin{array}{l}1913 \\
\text { 大正 } 2\end{array}$ & $\begin{array}{l}\text { 埋立会社(前市長 } \\
\text { 西川, 汽船·電鉄 } \\
\text { 会社社長ら) }\end{array}$ & $\begin{array}{l}\text { 浜大津-石場 } \\
\text { 約 } 7 \text { 万 } \mathrm{m}^{2}\end{array}$ & $\begin{array}{l}\text { 工費 } 25 \text { 万円, 湖岸逍遙道路, } \\
\text { 市街地建設等 }\end{array}$ \\
\hline 3 & $\begin{array}{l}1925 \\
\text { 大正 } 14\end{array}$ & $\begin{array}{l}\text { 埋立会社(大津市 } \\
\text { 長(中井), 大津商 } \\
\text { 業会議所) } \\
\text { 設計:県土木課の } \\
\text { 栗原技師 }\end{array}$ & $\begin{array}{c}\text { 浜大津-石場 } \\
\text { 幅 50-80間 } \\
\text { /約 } 22.5 \text { 万 m² }\end{array}$ & $\begin{array}{l}1.5 \text { 万坪の中島(湖畔ホテル, 温 } \\
\text { 泉旅館, 音楽堂, レストラン等) } \\
\text { 逍遥道路(幅員 } 10 \text { 間, 浜大津- } \\
\text { 帝国製麻工場間, 約 } 1.6 \mathrm{~km})\end{array}$ \\
\hline 4 & $\begin{array}{l}1929 \\
\text { 昭和 } 4\end{array}$ & $\begin{array}{l}\text { 埋立会社 } \\
\text { (大津商業会議 } \\
\text { 所, 阪神電鉄, 新 } \\
\text { 大阪土地) }\end{array}$ & 同上 & $\begin{array}{l}\text { 概ね同上 } \\
\text { 湖中に } 1.4 \text { 万坪の中島, 四遊郭 } \\
\text { 移転案, 湖岸一帯の遊覧道路 } \\
\text { (幅員 } 10 \text { 間)之逍遥道路(幅員 } \\
6 \text { 間乃至 } 3 \text { 間) } \\
\end{array}$ \\
\hline 5 & $\begin{array}{l}1932 \\
\text { 昭和 } 7\end{array}$ & $\begin{array}{l}\text { 都市計画滋賀地 } \\
\text { 方委員会(都市計 } \\
\text { 画大津湖岸埋立) }\end{array}$ & $\begin{array}{l}\text { 尾花川-石場 } \\
/ \text { 約 } 38 \text { 万 } \mathrm{m}^{2}\end{array}$ & $\begin{array}{l}\text { 湖岸道路(幅員 } 19 \mathrm{~m})(\mathbb{I} 1.3 \text { 線) } \\
\text { 湖岸に幅員 } 5.5 \mathrm{~m} \text { の遊歩道 } \\
\text { (詳細は本文参照) }\end{array}$ \\
\hline
\end{tabular}

(参考文献 : 1, 3 : 『大津市三十年史』 (1928)，2 : 京都新聞滋賀 版 1984 年 2 月 16 日付, $4:$ 朝日新聞滋賀版 1929年 1 月 16 日付, 5 : 「大津都市計畫街路網並埋立設計概要」（1932）） 
（1908-1911 年在任）の離任もあり，埋立計画は進捗し なかった。

直後の 1913 （大正 2）年の湖岸埋立計画の存在も既に 知られている ${ }^{20)}$. 西川に次いで大津市長をつとめた田村 善七や西川の前の市長の村田虎次郎（1902-1908 年在 任），地元民間会社社長らが設立を図った大津湖岸埋立 株式会社による計画である. 現浜大津港東から京阪石場 駅あたりまで約 7 万 $\mathrm{m}^{2}$ を埋め立てようという計画で, 湖岸には「逍遙道路」を設けて観光客を誘致し, 湖岸の 埋立地を貸地とするか売却することが有望な投資だと考 えられた。この「逍遙道路」の構想は，1932 年に都市 計画決定されて戦後に実現する大津市湖岸道路の原型に あたる構想として位置づけられる.

c) 逢坂山トンネル剩土を利用した埋立道路計画 (1914)

翌 1914 （大正 3）年 4月の大津市会において「湖岸道 路設置ノ為入琵琶湖水面占用シ道路完成ノ上八無償下付 习其筋へ請願ノ件」の請願書が議決された. 本請願は, 鉄道路線によって湖岸の大部分の交通・眺望が阻害され ていることを問題と捉え，湖岸逍遙道路を建設して市の 繁栄発展を推進することが急務であるとしたものである これは鉄道院が京都大津間の付替工事を実施するにあた り生じる残土の無償払下げを受けて, 湖岸水面を埋立て 道路の建設を行おうと寸るものであった ${ }^{211}$.この請願提 出者の一人が道遙道路建設の積極的推進者であった西田 與三郎 (8)である. 西田與三郎による後の大津市会での答 弁によると，トンネル剩土を利用した埋立と逍遙道路建 設の計画を大津市当局が設計し，これをふまえて剩土の 無償下附を市会に諮ったが，公民会の前身である大成会 の議員らが政治的理由により反対して否決され，実現し なかった 22), 23)。西田は市会議長（1919 年-）を経て都市 計画策定期には大津市長（1930-1933 年在任）を務めた 人物である. 北村重之助市議が西田をして「大津市に湖 岸逍遙道路を設けざれば何うしても大津市に降り来る遊 覧客を留めることは出来ぬと云ふことの熱心なる唱道 者 ${ }^{24} 」$ と評した (1929年 2 月の大津市会) が, 湖岸逍遙道 路の熱心な推進者であった。

\section{(2) 県市一体での湖岸埋立計画の推進 (1925)}

1925 （大正 14）年には，滋賀県知事・末松偕一郎 （1923-25 年在任）が琵琶湖協会を設けて遊覧施設整備 に乗り出したのを機に，大津市長・中井荘七（1922-26 年在任）が中心となり, 再び埋立会社の創設が図られ, 滋賀県土木課の栗原技師に依頼して湖岸埋立計画を作成 した.ここに湖岸埋立における滋賀県と大津市の強力な 協力体制が認められる。本計画は浜大津-石場播磨屋間 を約 90m 沖まで直線で埋立て, 幅員十間（約 18m）, 延長約 $1.6 \mathrm{~km} の 「$ 逍遙道路」とともに, 湖中には 1.5 万 坪 (約 5 万 $\mathrm{m}^{2}$ ) の中島を建設し，そこに湖畔ホテルの
ほか温泉旅館や各種娛楽場，レストランを含めた「歓楽 地帯」を設けるといったものであった ${ }^{25)}$. 大津市会での 森久右衛門による説明によれば，1923（大正 12）年の 鵜澤県内務部長の発案を受けて, 中井大津市長が末松県 知事と図り, 当時の市会議員や商業会議所議員らの有志 を創立発起人として, 県市協力のもと埋立事業の実現に 努めたという。しかし, 本事業案は鵜澤内務部長の兵庫 県への転任や中井市長の退職, 財界の不況等により実現 に至らなかった ${ }^{20 .}$

\section{（3）昭和初期の民間会社による埋立計画の出願（1929）}

1929 (昭和 4）年 1月 14 日，大正期の中井市長時代の ものとほぼ同じ内容の埋立計画が，民間の埋立会社によ って滋賀県一出願された。 これは琵琶湖国立公園の指定 を見据えたもので，計画案自体は「末松知事時代のもの をそつくり取つたもの」であり，浜大津-石場間を埋め 立て, 約 8.8 万坪 (約 22.5 万 $\mathrm{m}^{2}$ ) の埋立地を築造し, 湖 岸一帯には「幅員十間の遊覧道路」を建設して, これに 京町通の国道を移し，あわせて「六間乃至三間のいはゆ る逍遙道路」を設けるというもの, として報じられた. さらに湖南町地の湖中に 1.4 万坪（約 4.6 万 $\mathrm{m}^{2}$ ) の中島 を築き，ここに近代的遊覧施設を整備するという計画が 報じられた 27 . 本計画は, 先の県市一体の計画を引き継 ぎつつ，資金の問題を民間会社の主導で乗り越えようと するものであった.

本埋立出願の事業主体は大津商工会議所会頭・兼松寅 太郎と, 島徳蔵 (阪神電鉄社長) や井上千吉（新大阪土 地社長）らの出資者であった. 1929 年 2 月 14 日の大津 市会において，この埋立事業を後押しする「湖岸埋立促 成二関スル建議」が提出され，同日可決された. 以下， 大津市会会議録をもとにその建議の内容を示寸 ${ }^{28)}$. 建議 は, 過去の幾度の湖岸埋立計画が実現しなかったことを 「頗る遺憾」とし, この度, 島徳蔵ほか 2 名より出願し た湖岸埋立の促成の意見書を，市会の決議によって内務 大臣及び滋賀県知事に提出することを目的とした. 本計 画は, 川口堀-石場間を埋め立て, 「湖畔逍遙道路の新 設, 港湾整理等」を行い，遊覧施設を完成して市の発展 を期すものであると説明された：これは，大津市の商工 会議所の会頭である兼松が，大阪の財界の巨頭である島， 井上に出資を説き，「前に出来ましたる設計図其儘を踏 襲し縣に出願」したものであった.

建議提出者の一人である森久右衛門の市会での説明で は，「本市と致しましては重要なる財源を得まする一方 遊覧都市として一日も早く実現を致し，一つの遊覧地と して尚又多年の懸案であります, 湖岸問題に付きまして も, 解決の後に於ては其他種々利益もあるやに存じてお ります」，とその意義が訴えられた．また，湖岸埋立上 問題となる治水についても，「治水会其他」より「大変 
好感情を以て居られる」とその好感触を伝えた上で, こ れが実現するかどうかは，地元大津市が内務省と滋賀県 に対して「熱心不熱心」によって決まると主張した.

また，同じく建議提出者の北村竹次郎は，観光の現状 として, 昭和 3 年度の汽車汽船電車の乗降客数が七百万 を越え，阪本や石山には多数来客したにもかかわらず 「大津は殆ど素通りの有様」であり，その理由が大津の 湖畔に山に遊覧客の足を止めるような遊覧施設がないこ とにあるとした．特に湖岸が「水郷の大津に来て水に親 しむと云ふことが出来ないと云ふ有様」であることを問 題視し，「此埋立地を完成致しましてさうして遊覧設備 を完成し一大楽天地を設けると云ふことは市の発達の為 めに焦眉の急である」，「之が完成を助成することは大 津市発展の為め最大急務であると確信致す」と，埋立地 造成による湖岸の整備と遊覧施設の完成が急務であると 主張した.

この建議案は同日可決されたが，実現には至らなかっ た. その理由は内務省土木局が，治水上の観点から湖岸 の埋立を原則的に不許可と寸るとしたためである ${ }^{29}$.

以上のように，大津では国際リゾート地開発運動に先 駆け，市，県，資本家の各主体から，時に強力な協力体 制をもって，浜大津を中心とした「逍遙道路」や湖畔木 テルの建設を含む湖岸埋立計画が幾度となく企画・立案 された.ここでは湖岸の風致を利用した遊覧施設の必要 性は強く認識されており，また計画自体も技術的に裏付 けられた具体的な案が作られていた. 浜大津附近に関し て言えば, 逍遙道路は既に 1913 年の構想に認められ, 1925 年と 1929 年の計画案では幅約 $18 \mathrm{~m}$ とされたが，実 際に 1932 年にはほぼ同じ規模の幅員 $19 \mathrm{~m}$ の湖岸道路が 都市計画決定した。 なお浜大津-石場間の埋立計画案の 面積は, 1925 年の約 23 万 $\mathrm{m}^{2}$ と同程度の規模の計画が, 1932 年に都市計画決定された。これらの事実を鑑みる と，上述した計画は政治上，治水上の理由から実現には 至らなかったものの, その後決定された都市計画案へ引 き継がれた可能性が指摘できる.

\section{4. 都市計画街路網計画の策定過程と計画意図}

\section{（1）都市計画区域決定と「遊覧都市」計画の初動}

本章では，大津における都市計画街路網計画の策定の 過程と，その計画意図について明らかにする。

1923 (大正 12）年, 都市計画法 (旧法) の適用範囲 は人口 9 万以上の 25 都市に拡大され, 1928 (昭和 3) 年 1月には大津が都市計画指定都市に適用された. 1928年 8 月に第一回都市計画滋賀地方委員会が開催され，1929 年 6 月には大津の都市計画区域が決定された（北は坂本, 南は石山・瀬田を包含）。その決定が行われた第二回都
市計画地方委員会（1929.5.28）においては，区域決定の 理由として, 経済的発展や交通機関の完成のみならず,

「都市計畫上特殊の考慮を要すへきもの」としての史蹟 名勝の保存が謳われていた. その決定理由書には，大津 において「人口の増加, 工場, 住宅の濫設に委せんか貴 重なる名勝史跡は全く破壊し去られ悔を後世に残すの恐 なしとせす．此故を以て大津市 (ママ) 都市計畫区域とし て附近町村を併せたる相當拡大の地域を包含せしめ依つ て将来産業及名勝史蹟の地として発達の基礎を確立せむ とす」とあるが 30)，ここには社会基盤整備による産業発 展と名勝史蹟の保存の, 二つの意図が認められる. 後に 都市計画滋賀地方委員会技師として街路網や埋立計画の 策定に関わる塩原三郎は，この都市計画区域決定時に示 された名勝史蹟の地としての発展方針について，「既に 遊覧都市計画の必要を論じて居る」ものと評している ${ }^{31)}$.

\section{（2）都市計画街路網及び埋立計画の決定とその意図 a) 都市計画決定の経緯}

1931（昭和 6）年 8 月に滋賀県知事・除野康雄によっ て「琵琶湖をめぐる大遊覧施設計画 32 」が県参事会の席 上で発表され，柳ヶ崎における国際リゾート開発の具体 的内容が明らかにされた。 その前年の『建築世界』

（1930年 3月発行）誌上でなされた遊覧施設計画の報告

「太湖畔に描出寸理想の遊覧都市」に，大津の街路網計 画, 地域指定の素案が示された(9)。ここでは緊要な計画 として, 湖岸を埋立てつくる「逍遙道路」, 浮島に四遊 郭を移転して設ける一大歓楽境, 尾花川に湖岸を利用し た「一大公園」の建設が挙げられ，「将来これが完成の 暁は都市の美観を増大し，大津の面目は一新して世界に 誇り得る遊覧都市として価值づけられる」との期待が述 心゙られている33). なお，市当事者の言説として，「これ 等の諸計画を机上の空論の如く考へてみる人々が多いの は遺憾千萬 $(\cdots)$ 決して夢物語ではない, 事業の性質上 莫大な経費を要するから一時に着手することが出来ない が徐々に最初の方針に基づき進めて行く」という方針が 紹介されている.

実際に，大津都市計画街路網並埋立は第三回都市計画 滋賀地方委員会（1932年 9 月 8 日）において可決し, 同 年 9 月 30 日に内閣の認可を受けた. 『都市計畫滋賀地 方委員會第三回議事録』所収の「街路決定理由書」には, 大津市は地方政治, 教育, 経済の中心をなすのみならず

「其の附近地と共に景勝, 史蹟に富久我國屈指の遊覧地」 であるにもかかわらず, 道路, 鉄道, 軌道等の配置, 連 絡に欠陷多く，社会上，経済上の損失が大きいことが明 言されている. また, 埋立決定理由書には, 市街地の過 密の緩和，ならびに将来の都市計画施設の実現に「相當 の土地面積を要する」ことが湖岸埋立の理由として挙げ られ, 加えて, 湖岸の堆砂を除去して治水のための湖岸 
整理を合わせて行う必要性も理由に挙げられた ${ }^{34)}$.

本議案の委員会での説明は，櫻井哲三（県内務部土木 課長）によるが，櫻井は大津が今や「京阪大都市の郊外 地」の傾向を強め，その経済は「一般に産業不振なる當 地に漸く施設の完備を待つて遊覧地として大いに其の特 色を発揮せんとする傾向顕著」であり，本計画もこの傾 向に基づいている，と述べた。埋立計画については「街 路網の配置系統上極めて必要なるは勿論大津市街の発展, 遊覧施設瀬田川上流膳所瀬田両湖岸の開発並に治水及経 済等総合計画上極めて重要なる計画」と，都市計画の根 本計画として位置づけていた。 なお，同委員会には内務 技師榧木寛之が臨席していた．塩原と榧木の関係につい ては後述する.

計画案の説明後の質疑のなかで，大津市会議員中野清 次郎から, 大津湖岸埋立については度々埋立出願があつ たがその都度「途中に於て消へて居る」こと，「大津市 としては遊覧施設を島の所に計畫したいと云ふ説を持つ て居る」ことが述べられ，湖中に中島を造り遊覧の施設 に充てるという案が反映されていないことの理由を尋ね た. 櫻井は遊覧施設整備の趣旨自体は認めつつも, 中島 を造ることは「治水其他の関係上」から見合わせたと回 答した.

\section{b) 街路網構成の意図}

街路網構成の意図を明らかにするために，都市計画地 方委員会発行の『大津都市計画街路網並埋立設計概要』

（1932）の内容を精査する．本設計説明書には「街路網 構築上の課題」として, 主要道の幅員狭小, 屈曲, 自動 車交通の不備, 補助線の不足, 駅 - 港湾との相互連絡の 不十分が挙げられていた ${ }^{35)}$.また，史蹟名勝に富む遊覧 地であるにもかかわらず「風致を考慮したる遊覧的道路 の施設統制なきこと．殊に大津湖岸に於て著しきこと」 が課題として挙げられていた.

これに対し街路選定方針としては，「極言すれば当区 域の地方的陸上交通は殆どバスに依るべきものと思惟す るものなり。即ち街路網の構成は実に之を基準とす」と， バスを中心とした交通網の方針とともに，名勝地連絡に よる遊覧交通系統の確立が示された。具体的な街路網の 構成は，第一に交通中心となる浜大津を中心に各方面一 主要幹線を放射し, 次いで大津, 石山各駅を中心として 重要な集落, 古跡名勝の連絡を図り，新たな土地の利用 開発を図るための補助幹線を設ける，といったものであ った.このとき，将来の都市交通機関としてのバスの利 用が見込まれ，五十一の路線が定められた。これにより 市域の交通問題の解消が図られた.

また, 街路整備のための湖岸埋立は, 街路網の構成上 も「最も重要」な要件と位置付けられており, 湖岸道路 についても「遊覧都市としての面目上研究を要すべく湖 岸道路を初め之を連絡道路等は全て模範的なるものたら
しむるを要す」，「琵琶湖並びに瀬田川浻岸道路は特に 風致を重んじ，沿岸地の利用を増進する」という方針が 明示された，すなわち，湖岸道路を中心として湖岸の整 理と風致整備を行い，これによって近代的な公共空間を 創出することが意図されたといえる.

\section{(3) 街路網中の遊覧道路とその計画・設計案}

前述の通り，都市計画街路網は，名勝地や遊覧施設を 連絡する遊覧道路，風致や美観に優れた逍遙道路の充実 が図られて策定された。 そこで，都市計画街路網の計画 路線の説明文をもとに，湖岸道路とそれに加えて「遊覧 道路」と明言されている路線，史蹟名勝の連絡に資する

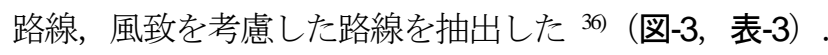
以下，具体的な計画意図を考察する.

\section{a) 湖岸道路}

都市計画決定された街路網のうち，「一貫せる遊覧的 交通幹線にして湖岸遊覧都市構成上最も重要なる路線」 として計画策定者である塩原三郎が位置づけていたのが， II.1.2 線（順に等.類.号）（濱大津港比覘又辻線）及び II.1.3 線（濱大津港寺邊線）である ${ }^{37)}$. 前者の II.1.2 線は,

「一般地方交通上極めて重要なるのみならず柳ヶ崎, 唐 崎, 新唐崎等湖岸の史蹟名勝地を連ね湖岸遊覧道路とし ての目的を有するもの」として位置づけられた ${ }^{38)}$. II.1.3 線もこれと同様に，「一般地方交通上重要なるのみなら ず遊覧交通の目的を有する路線」とされた。湖岸道路は， 埋立地においては湖岸に面して配置され（図-4），幅員 $19 \mathrm{~m}$ として車道四車線を取り，湖岸側片側に幅員 $5.5 \mathrm{~m}$ の「遊歩道」を設けるものとして基本設計がなされた ${ }^{399}$. 二等一類の都市計画街路の標準断面が，幅員 $22 \mathrm{~m}$, 中央 に $16.5 \mathrm{~m}$ の車道部, 両側に合わせて $5 \mathrm{~m}$ の幅員の遊歩道 という構成であったことを鑑みれば，湖岸道路の遊歩道 は湖岸の風致に配慮したゆとりのある設計であったとい える 40)。また，都市計画街路の街路樹については，幅員 $2.75 \mathrm{~m}$ 以上の歩道と湖岸歩道に, $5 \mathrm{~m}$ の間隔で街路両側に 植樹することが計画された ${ }^{41)}$.

\section{b) 都市計画街路網中の遊覧道路}

都市計画決定された路線のなかで，遊覧交通の目的を 有する道路としては，まずは遊覧幹線道路である湖岸道 路が挙げられ，そのほかに市内の名勝地である唐崎，穴 太，日吉神社，延暦寺，膳所城趾，茶臼山等をそれぞれ 連絡する道路，瀬田川右岸ならびに三井寺周辺の山手の 史蹟名勝地を連絡する道路が確認できた。また，瀬田川 沿岸, 加えて粟津ヶ原の道路が, 風致を考慮する道路と して挙げられた.

\section{（4）都市計画技師・塩原三郎とその来歴}

上述した街路網と埋立計画の主たる策定者は，都市計 画滋賀地方委員会技師・塩原三郎(10) (同在任期間 1929 


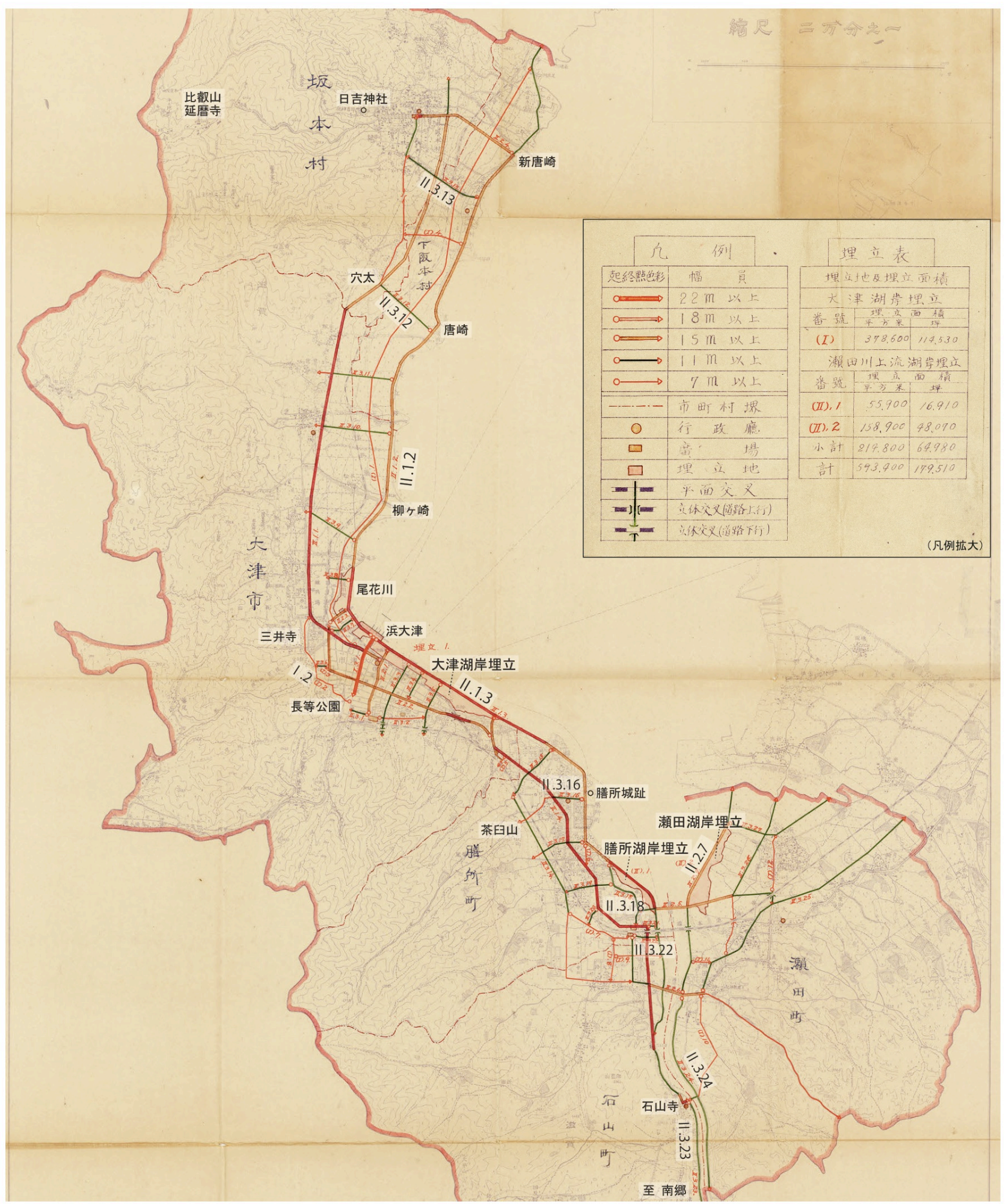

図-3「大津市街路并埋立決定ノ件 都市計画街路網図」（部分）（「第三回委員會書類」都市計畫滋賀地方委員會, 所収） （1932年 2 月作成，原図（1110mm×670mm）をもとに湖岸埋立計画,遊覧道路及び風致道路, 著名な名勝地を筆者加筆）

年 11 月～1934 年 6 月）である. 塩原は 1929（昭和 4) 年 11 月に内務省復興局第一出張所から都市計画滋賀地 方委員会へ出向となった．塩原の自伝 42)によれば，塩原 が着任したとき既に都市計画区域の指定がされており， 街路, 用途地域, 公園, 風致地区の策定が塩原の役割と して期待されていたという。都市計画の策定においては,
内務省都市計画課の指導を受けたが，なかでも榧木宽之 （土木主任技師）と桜井英記（技師）から「格別の」指 導を受け，また都市計画京都地方委員会からも実務的指 導を受けたとしている. 湖岸道路計画については治水上 の制限を受けるため, 内務省大阪土木出張所の方針を受 けて検討する必要があったが，塩原は坂本助太郎（大阪 
表-3 都市計画街路網中の遊覧道路及び風致道路

\begin{tabular}{|c|c|}
\hline $\begin{array}{l}\text { 路線 } \\
\text { (順に等. } \\
\text { 類.号) } \\
\end{array}$ & $\begin{array}{l}\text { 路線の説明抜粋 } \\
\text { (カナをかな字に，旧字体を新字体に修正) }\end{array}$ \\
\hline 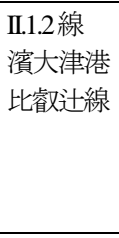 & $\begin{array}{l}\text { 濱大津-大津埋立地（湖岸）-別所-柳ヶ崎-比㖫辻 } \\
\text { 「一般地方交通上極めて重要なるのみならず柳ヶ崎, 唐 } \\
\text { 崎, 新唐崎等湖岸の史蹟名勝地を連ね湖岸遊覽道路として } \\
\text { の目的を有するものにして幅員一六米を標隻とし大津都市 } \\
\text { 計画埋立地に於ける湖岸道路は湖岸側の遊歩道の関係上特 } \\
\text { に幅員一九米とし」 }\end{array}$ \\
\hline $\begin{array}{l}\text { II.1.3線 } \\
\text { 濱大津港 } \\
\text { 寺邊線 }\end{array}$ & 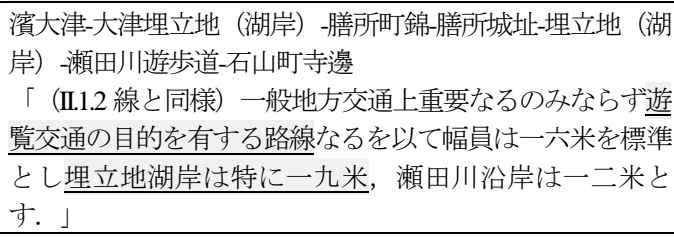 \\
\hline $\begin{array}{l}\text { II.3.12線 } \\
\text { 唐崎坂本 } \\
\text { 線 }\end{array}$ & 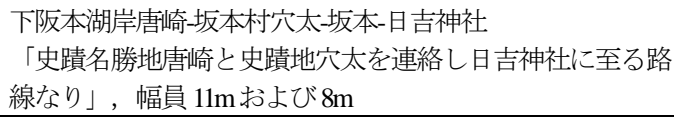 \\
\hline $\begin{array}{l}\text { II.3.13 線 } \\
\text { 下阪本港 } \\
\text { 坂本線 }\end{array}$ & $\begin{array}{l}\text { 下阪本-松ノ馬場道坂本 } \\
\text { 「現在道路の両側に松樹多く風致に富み，湖岸より日吉神 } \\
\text { 社，延暦寺に至る連絡遊覽道路に相當するものにして風致 } \\
\text { 存考虑し幅員を一二米とす.」 }\end{array}$ \\
\hline $\begin{array}{l}\text { I.3.16線 } \\
\text { 膳所茶臼 } \\
\text { 山線 }\end{array}$ & $\begin{array}{l}\text { 膳所城址-膳所神社-相模川右岸茶臼山 } \\
\text { 「史蹟名勝地を連絡する路線」，幅員 11mおよび8m }\end{array}$ \\
\hline $\begin{array}{l}\text { II.3.23 線 } \\
\text { 寺邊南郷 } \\
\text { 線 }\end{array}$ & $\begin{array}{l}\text { 寺邊-石山寺瀬田川右岸-平津-南郷鹿跳橋 } \\
\text { 「當路線は瀬田川右岸史蹟名勝地を連絡する遊覽道路に相 } \\
\text { 當し, 起点より南郷洗堰に至る区間は風致を考慮し幅員二 } \\
\text { 三米とし」 }\end{array}$ \\
\hline $\begin{array}{l}\text { I.2線 } \\
\text { 上栄町別 } \\
\text { 所線 }\end{array}$ & $\begin{array}{l}\text { 上栄町-長等公園-長等神社-三井寺境内-別所 } \\
\text { 「山手史蹟名勝地遊覽道路に相當し幅員八米とす.」 }\end{array}$ \\
\hline
\end{tabular}

\section{$\square$ 風致を考慮する道路}

\begin{tabular}{|c|c|}
\hline $\begin{array}{l}\text { II.2.7 線 } \\
\text { 橋本南大 } \\
\text { 萱線 }\end{array}$ & $\begin{array}{l}\text { 瀬田町橋本瀬田橋瀬田川左岸-大江-埋立地（湖岸）-南大萱 } \\
\text { 「瀬田川の沿岸は風致上幅員一二米とし」「都市計画埋立 } \\
\text { 地湖岸の部分は幅員一六米とし」 }\end{array}$ \\
\hline $\begin{array}{l}\text { II.3.18線 } \\
\text { 中庄石山 } \\
\text { 駅線 }\end{array}$ & $\begin{array}{l}\text { 中庄湖岸本多神社-粟津松原-石山駅 } \\
\text { 「粟津松原は粟津晴嵐の称あり. 近江八景の一なるも附近 } \\
\text { 工場の建設並に市街化により著しく風致を損傷せられつつ } \\
\text { あり．道路両側に於ける松樹保存を考慮し，幅員一二米と } \\
\text { す.」 }\end{array}$ \\
\hline $\begin{array}{l}\text { II.3.22 線 } \\
\text { 石山駅膳 } \\
\text { 所線 }\end{array}$ & $\begin{array}{l}\text { 石山駅粟津道瀬田川右岸 } \\
\text { 「沿道の風致を考慮し幅員一二米とす」 }\end{array}$ \\
\hline $\begin{array}{l}\text { II.3.24線 } \\
\text { 橋本瀬田 } \\
\text { 川左岸線 }\end{array}$ & $\begin{array}{l}\text { 橋本瀬田川左岸瀬田町下田上村境 } \\
\text { 「風致を考慮し幅員一二米とす」 }\end{array}$ \\
\hline
\end{tabular}

(「大津都市計畫街路網並埋立設計概要」（都市計畫滋賀地方委 員會，1932）「第三回委員會書類」所収，をもとに筆者作成）

土木出張所）から「親切な指導を受けることができた」 と述懷する．街路計画においては測量調查が必要であっ たため，補佐として復興局から北郷哲也技手を，助手と して川上富三，松岡勇，堀井信春を迎えて測量チームを 編成し，約 3 年という比較的短期間で街路計画の決定を 実現させた。

塩原三郎の出自について述べる．塩原は 1903 （明治

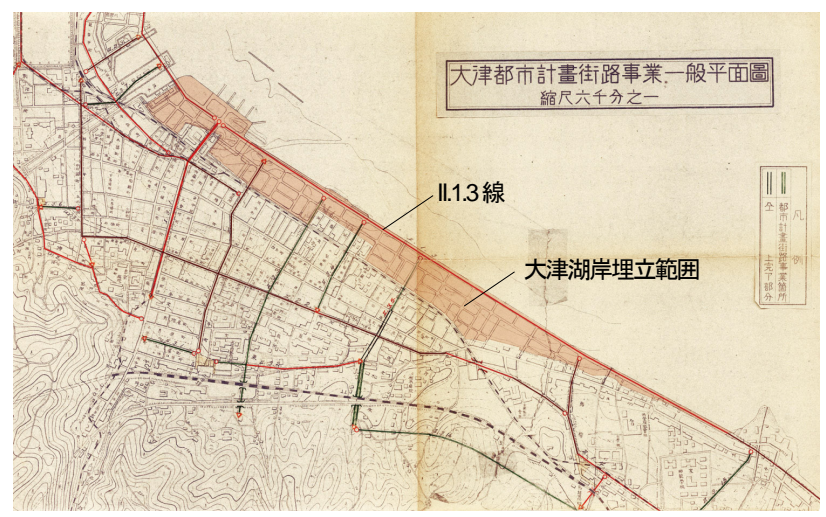

図-4 大津都市計画街路事業一般平面図（原図は「第十二回都 市計畫委員會関係書類」（1941）に所収，一部筆者加筆）

36）年に前橋に生まれ，水戸高等学校を出て，東京帝国 大学工学部土木工学科では道路工学を専攻し，1928 年 3 月に卒業した．卒業後に務めた内務省の復興局では芝公 園の整備に関わり，ここで山田博愛（当時東京第一出張 所長）や榧木寛之（内務省都市計画課土木主任技師）と 交流を持った．滋賀県が「京都大学の勢力圈」であった にもかかわらず，塩原が滋賀県一出向したのは，榧木寛 之の意向によるものであったという．滋賀都市計画地方 委員会の幹事を務めていた櫻井哲三 (内務部土木課長) は，塩原にとっては東大土木の先輩であり，榧木とは東 大土木の同期であった．塩原は，自身の滋賀県への出向 はこうした人間関係によるものだと記している ${ }^{43) .}$

\section{5. 都市計画湖岸埋立計画の計画意図}

\section{(1) 湖岸埋立計画の内容とねらい}

本章では，大津における都市計画湖岸埋立計画の具体 的内容と，その計画意図について明らかにする. 大津の 都市計画埋立計画は第三回都市計画地方委員会にて審議 され，街路計画とともに 1932 （昭和 7）年 9 月 30 日に 内閣の認可を受けた. その内容は表-4の通りである.

湖岸埋立計画の具体的内容とその計画意図を，主に 『大津都市計畫街路網並埋立設計概要』（1932）に基づ いて示す。この埋立計画立案にあたって都市問題として 認識されていた課題は，第一に，平坦地に乏しく狭長か つ人口稠密である大津市域において既存都市の改造が至 難であったことが挙げられる. 大津市の中心地において は，都市施設の不足ならびに土地の不足は顕著であり， 市街発展のために湖岸埋立により「相當の埋立地を獲得」 する必要が認識されていた。 次に，湖岸の個人的な占用 もみられるなど「衛生美観上統制なく都市構成上誠に不 経済の極に達したる」状態が問題として認識されていた. 加えて, 遊覽施設整備の必要性が認識されていた。 その 一方, 内務省は淀川の治水上の理由から琵琶湖湖岸の埋 
表-4 大津都市計画湖岸埋立計画（「第三回委員會書類」 (都市計畫滋賀地方委員會, 1932) をもとに作成)

\begin{tabular}{|c|c|c|c|}
\hline 事業 & 計画の諸元 & $\begin{array}{l}\text { 埋立地 } \\
\text { 土地利用計画 }\end{array}$ & $\begin{array}{l}\text { 埋立事業 } \\
\text { 収支計画 }\end{array}$ \\
\hline $\begin{array}{l}\text { 大津 } \\
\text { 湖岸 } \\
\text { 埋立 }\end{array}$ & $\begin{array}{l}\text { 大津市別所地先 } \\
\text {-膳所町錦地先 } \\
\text { 湖岸延長約 } 3500 \mathrm{~m}, \\
\text { 地積約 379,600 }{ }^{2} \\
\text { 湖岸道路幅員 } 19 \mathrm{~m}, \\
\text { 遊歩道 5.5m, } \\
\text { 公園四箇所 } 26,400 \mathrm{~m}^{2}\end{array}$ & $\begin{array}{l}\text { 街路 31.95\% } \\
\text { 公園 } 6.95 \% \\
\text { 荷揚場 } 1.2 \% \\
\text { 宅地 } 59.4 \% \\
\text { 鉄道用地 } 0.5 \%\end{array}$ & $\begin{array}{l}\text { 収入 } \\
\text { 5,433,000円 } \\
\text { 支出 } \\
\text { 3,733,000 円 } \\
\text { 売却益 } \\
\text { 1,700,000円 }\end{array}$ \\
\hline $\begin{array}{l}\text { 膳所 } \\
\text { 湖岸 } \\
\text { 埋立 }\end{array}$ & $\begin{array}{l}\text { 膳所町中庄地先 } \\
\text { - 膳所湖岸 } \\
\text { 湖岸延長約 } 1000 \mathrm{~m}, \\
\text { 地積約 55,900 } \mathrm{m}^{2}, \\
\text { 湖岸道路幅員 } 19 \mathrm{~m}, \\
\text { 公園・広場 } 1,300 \mathrm{~m}^{2}\end{array}$ & $\begin{array}{ll}\text { 街路 } & 43.8 \% \\
\text { 公園 } & 2.3 \% \\
\text { 宅地 } & 53.9 \%\end{array}$ & $\begin{array}{l}\text { 収入 } \\
451,500 \text { 円 } \\
\text { 支出 } \\
\text { 320,000 円 } \\
\text { 売却益 } \\
\quad 131,500 \text { 円 }\end{array}$ \\
\hline $\begin{array}{l}\text { 瀬田 } \\
\text { 湖岸 } \\
\text { 埋立 }\end{array}$ & $\begin{array}{l}\text { 瀬田町大江地先 } \\
\text {-南大萱地先 } \\
\text { 湖岸延長約 } 1100 \mathrm{~m}, \\
\text { 地積約 } 158,900 \mathrm{~m}^{2}, \\
\text { 湖岸道路幅員 } 16 \mathrm{~m}, \\
\text { 公園・広場 } 8,200 \mathrm{~m}^{2}\end{array}$ & $\begin{array}{ll}\text { 街路 } & 25.3 \% \\
\text { 公園 } & 5.2 \% \\
\text { 宅地 } & 69.5 \%\end{array}$ & $\begin{array}{l}\text { 収入 } \\
662,400 \text { 円 } \\
\text { 支出 } \\
\quad 620,000 \text { 円 } \\
\text { 売却益 } \\
\quad 42,400 \text { 円 }\end{array}$ \\
\hline
\end{tabular}

立を不許可とする方針を採っていた ${ }^{44}$.

同設計書には「天然の景勝に優れ太古以来幾多の史蹟 名勝に富む」大津一帯が「琵琶湖湖岸遊覧都市として其 の特異性を発揮せんとするに於ては大津都市計畫上湖岸 の整備施設の問題は極めて重要」（大津都市計畫埋立 「計畫撰考」）とある. 塩原は大津市が遊覧都市として 発展するためには, 湖岸逍遙遊覽の目的を達成する道路 のほか，旅客遊覧および貨物輸送のための港湾荷揚場施 設，遊覽施設および湖畔公園の必要性を挙げたが，これ らの実現の手段として湖岸埋立が必要であるとした ${ }^{45}$.

埋立地の選定基準としては，交通の完備や都市施設の 充実のほか，事業予算上の問題として「宅地を造成して 之を賣却し本事業費に充當せしむる」ことが重要視され た. 都市計画滋賀地方委員会書類「大津都市計画埋立収 支概算帳」によると，計画段階の事業収支見込みについ ては表-4の通りであり，収入には若干の受益者負担金を 含みつつも，その大部分は宅地の売却金を見込んで計画 立案されていた ${ }^{46}$.

\section{(2) 湖岸の美化}

埋立においては湖岸の美化も考慮され，湖岸道路を中 心に「市民並に遊覧客をして還境 (ママ) の美を感得せし むること」が計られた．大津湖岸埋立区域では湖岸遊歩 道に加えて，四公園の設置が計られたが，それぞれ「湖 岸遊歩道を助長し湖岸の風光を感得しうる」帯状公園,

「疏水を挟みて一帯の風致を助長せんとするもの」,

「遊覧港に接し特に遊覧客の休養に供するもの」，「呼 次公園に接し市民保健休養の目的を達しうべきもの」と して，その公園総面積は約 26,500m² で，埋立地総面積の
約 7\%に相当する規模の公園が計画された.

大津市付近の水面の管理は, 琵琶湖の水面は公有水面 法に基づき滋賀県が，瀬田川河道は河川法に基づき内務 省大阪土木出張所が行っていた，そのため，湖岸埋立は 滋賀県が許認可を行い，瀬田川沿いの工作物や浚渫は内 務省大阪土木出張所が許認可を行っていた. 実態として は 1923 （大正 12）年 11月の内務省通牒以降，内務省大 阪土木出張所は湖岸埋立について治水上不許可の方針を とっていた. そのため埋立計画の策定にあたって，とり わけ治水上の問題に配慮する必要があった。これに対し て塩原らは，大津湖岸埋立では湖岸を美化し乱雑を除去 するとともに，湖岸の塵芥の棄捨污物の沈滞を防止する ことを考慮することで，埋立許可を得ることを図った． 膳所，瀬田の埋立においても大津と同様に，湖岸埋立の 許可を得るために, 治水上埋立地湖岸線の形状を考慮し, 「水流を良好ならしむる」ことを設計に含んだ。これら は内務省土木出張所との協議の結果であった ${ }^{47}$.

\section{6. 遊覧施設整備計画の策定}

\section{（1）大津市における遊覧施設の現況とその認識}

本章では法定都市計画に含まれない遊覧施設整備案の 具体的内容とその計画意図について明らかにする.1933 （昭和 8）年 4 月，周辺市町村合併を成功させた大津市 は観光課を設置した．都市計画街路網及び埋立計画の策 定を担った塩原三郎（都市計画嵫賀地方委員会技師）が 内務省の官吏でありながら同課の嘱託を務めた．在任期 間は 1933 年 4 月から 1934 年 2 月である。塩原は観光課 の設置と同時に複数の雑誌記事を発表している.まず,

「新大津市と都市重要施設」（都市公論，1933.4） と題 する記事の中で，塩原は，合併拡大した新大津市のため の都市重要施設として，一に交通施設，二に衛生施設， 三に遊覧施設を挙げたが，特に系統配置を考慮して適切 な遊覧施設をなすことは湖岸道路を中心とする交通機関 の改良と合わせて「遊覧都市として特異性を発揮する上 に於て極めて緊要である」と位置づけていた ${ }^{48)}$. また,

「休養地としての大津及びその近郊」（大大阪，1933.4 と題する記事のなかで，遊覧都市としての発展が目指さ れているにもかかわらず，大津市が休養遊覧地として一 向に名声を拡大し得ていないこと，またその理想と実際 の状況の間に大きな隔たりがあることが課題として指摘 された ${ }^{49}$. 具体的には，休養地の保存開発，休養地相互 の関係の改善，遊覧交通之休養遊楽施設の充実，都市美 の考慮等が課題として挙げられていた ${ }^{(11)}$. この隔たりを 埋める第一の手段として期待されたのが湖岸埋立事業と 湖岸道路の築造であった。 


\section{（2）大津市における遊覧施設整備構想}

大津市観光課の最初の重要な業務は，大津市の観光に 関する調査を行うことであった。これを担ったのが塩原 三郎と佐藤昌（当時は滋賀県農林技手）であり，その調 查の結果ならびに計画提案は『大津市観光施設調查報告 書(12)』（副題「大津市の観光客誘致策」，大津市観光課発行， 1933 年 6 月） と題する一冊の報告書にまとられた（図2）. 同書は大津市の観光産業の統計，名勝地の現況な どの現況調査（第一篇）と，遊覧施設の整備計画（第二 篇）からなる．以下では，この塩原・佐藤らの遊覧施設 計画提案を取り上げ，都市計画と一体的に考えられた遊 覧施設整備構想の詳細を明らかにする。

まず，同書冒頭の「緒論」のなかで，観光事業の意義 が述べられている50．すなわち，観光事業とは「如何に して此等風景及文化を資源化し利用して経済価值を増大 せしむるかといふ事」であり，「自然の風光及文化美術」 の価値を「慰楽，休息，宿泊，食事，交通の各施設の連 絡を全う」させ，最大の価值を発揮するものとした.

第二編「計画」では，具体的に設備すべき遊覧施設と して十八の項目が挙げられた（表-5）。 なかでも，都市 計画事業による埋立湖岸道路は重要施設に位置づけられ たが，これは「今日朝の湖或は美しい比良の夕景を眺め ようと思つても腰を落ちつける所は殆んどない」状況に 対して，そのような場所を設ける必要性が挙げられた。 栗津ヶ原の再現も埋立に伴う計画であったが，新設街路 の建設にあたり，松林の景観の再現が挙げられた。その ほか，遊覧施設の整備項目として挙げられたのは，主と して公園や遊園地の改良であり，河畔・湖畔の整備であ った．これらに共通寸るのは，近世的名所や水辺の「近 代化」である，逍遙道路，ドライブウエイ，休咊所や広 場の築造・整備，ホテル・レストランの設置など，観光 行動の近代化にともない新たに生まれた場所への要求を 満たすことがその目的であった．塩原らが作成した観光 施設計画は法定計画ではなかったが，今日的な言葉で言 えば市の観光まちづくりマスタープランとして機能させ ようとしたものと考える. しかし，その作成直後は，小 学校の建設等が優先され，遊覧施設整備がすぐに進捗し たわけではなかった51).

\section{7. 都市計画湖岸埋立及び道路の実現過程}

湖岸埋立は，都市計画決定後すぐには実現しなかった が，大津市は1932-33年に滋賀村，膳所町，石山町と合 併し，都市計画事業の執行の準備を整えていた．前述し た『大津市観光施設調査報告書』においても湖岸埋立は

「緊急実施すべき」必要がある事業とされ，その目的は 「道路，港湾，公園等の各種公共施設を為すと共に湖岸
表-5 塩原・佐藤による遊覧施設整備案 （『大津市観光施設調查報告書』（1933）をもとに作成）

\begin{tabular}{|c|c|}
\hline $\begin{array}{l}\text { 遊覧施設 } \\
\text { 整備項目 }\end{array}$ & 主な整備の説明(「」内は引用) \\
\hline $\begin{array}{l}\text { 石山公園の } \\
\text { 新設 }\end{array}$ & 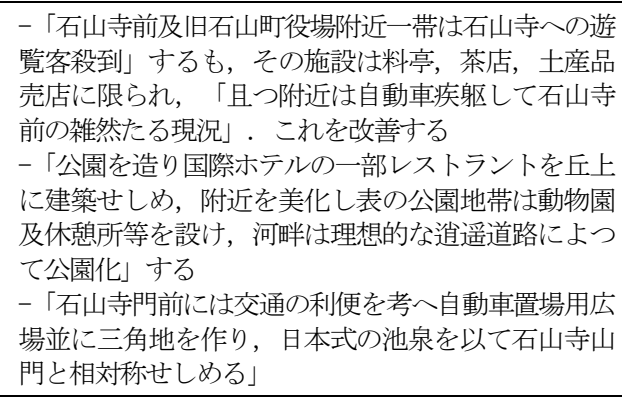 \\
\hline $\begin{array}{l}\text { 南郷遊園地 } \\
\text { の新設 }\end{array}$ & 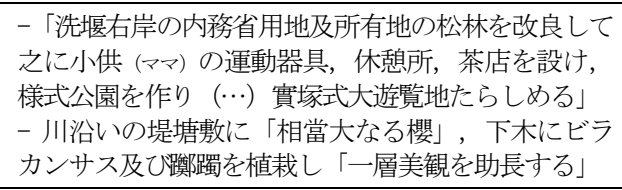 \\
\hline $\begin{array}{l}\text { 柳ケ崎遊園地 } \\
\text { の新設 }\end{array}$ & $\begin{array}{l}\text { - 国際ホテルは「比較的大衆的に設備せられること } \\
\text { を欲」し，「京都方面の人客及阪本，主井寺の帰途 } \\
\text { 客の足止地として }(\cdots) \text { 柳ヶ崎一帯を大公園となし } \\
\text { 理想的施設をな」し，「大津市の一大名所」として } \\
\text { 「人客を引く」 }\end{array}$ \\
\hline $\begin{array}{l}\text { 長等公園の } \\
\text { 改良 }\end{array}$ & $\begin{array}{l}\text {-「公園的機能に於ても遊覧客誘致に於いても重要な } \\
\text { る位置」にあるため, 入口の改造や噴水, 広場, 児 } \\
\text { 童遊園の改良・整備, 崖地の整備, 滝の新設と附近 } \\
\text { の施設, 眺望のための樹木伐採, 桜の植栽など } \\
\text { (佐藤昌「長等公園改良図及び改良計畫説明書」参 } \\
\text { 照, と記載) }\end{array}$ \\
\hline 水泳場施設 & $\begin{array}{l}\text {-「柳ヶ崎へ至る交通の便を計る事は重要」, } \\
\text {-「水泳場施設を完備せしめ以と大津市への人客を } \\
\text { 益々ひきつける」 }\end{array}$ \\
\hline $\begin{array}{l}\text { 膳所城址の } \\
\text { 公園化 }\end{array}$ & $\begin{array}{l}\text { - 膳所方面で位置, 史蹟, 風致随一であるため「維 } \\
\text { 持及管理を行ふ事は公園の配置系統上必要」 }\end{array}$ \\
\hline $\begin{array}{l}\text { 粟津ヶ原の } \\
\text { 再現 }\end{array}$ & $\begin{array}{l}\text { - 近江八景の一つにもかかわらず「今日の粟津は産 } \\
\text { 業の為に破壊せられて殁ど昔の面影を止めない」, } \\
\text { 保護するには手遅れであるため, 「附近湖岸の埋立 } \\
\text { に當り快適なる湖岸通路 (ママ) を作り適當に松を植栽 } \\
\text { して以て新晴嵐を再現せしむる」 }\end{array}$ \\
\hline $\begin{array}{l}\text { 宇治川ライン } \\
\text { の風致助成 }\end{array}$ & $\begin{array}{l}\text {-「比較的変化なる風景名勝を遊歴して愉快に楽しむ } \\
\text { 事が出来る」ので, 「田用水邊地には櫻及楓を多数 } \\
\text { 植栽し, 以て沿岸の美を増加せしむる」 }\end{array}$ \\
\hline $\begin{array}{l}\text { 茶臼山の } \\
\text { 開発 }\end{array}$ & $\begin{array}{l}\text {-「人の知る所少いのは全くその順路の不備にして設 } \\
\text { 備のない為め }(\cdots) \text { 船岡山公園の如くに四園を利便 } \\
\text { にする」 }\end{array}$ \\
\hline $\begin{array}{l}\text { 山手逍遥道 } \\
\text { 路の築造 }\end{array}$ & $\begin{array}{l}\text {-「市街地背部に渡る山陵地は湖水を俯瞰しうる極め } \\
\text { て快適なる散策地」である. 今は道路がないが, } \\
\text { 「小径を造ればその良コースとなす」 } \\
\text { - 大津営林署と協力して, ドライブウエイを設ける }\end{array}$ \\
\hline その他 & $\begin{array}{l}\text { 埋立湖岸道路及都市計画・諸公園の築造，志賀神宮 } \\
\text { の創建，総合運動場のー新設，幻住庵の再建，ゴルフ } \\
\text { 場の新設，ボートレースコースの統一 }\end{array}$ \\
\hline
\end{tabular}

整理，湖岸ドライブ道路，遊歩道等を完備せしめる」こ と，「遊覧都市としての面目を一新」し「大津市の躍如 たる活躍を発揮せしむる」ことと説明された，以下では， 都市計画決定された湖岸埋立の実現の過程を示す.

\section{（1）大津（尾花川）湖岸埋立事業とその設計}

大津（尾花川）湖岸埋立は滋賀県営埋立事業として事 
業化され，1937（昭和 12）年 5月頃に着工，1942（昭和 17）年 6 月に竣工した. 埋立地 21,325 坪（7.03ha）のう ち，13,000 坪（4.3ha）を住宅地として売却し，その売却 金と大津市からの寄附金が工費に充てられた ${ }^{52)}$.

この埋立計画は, 砂本によれば国際観光ホテルとして の琵琶湖ホテル（1934 年 10 月開業）の建設計画の進捗 と同時期，1931 年 10 月には，浜大津-柳ヶ崎間の道路を 外客誘致のドライブウエーに適するものに改良すべく, 県土木課において設計がなされていた ${ }^{53}$. しかしその後 も事業は寸ぐには具体化しなかった.

その後の本埋立事業及び湖岸道路の設計変更について, 1935（昭和 10）年 4月の大阪朝日新聞滋賀版が報じてい る.これによれば，都市計画地方委員会は「大津市観音 寺町第二疏水突堤から大商艇庫までの湖岸道路を理想的 な湖畔逍遙道路たらしめる心゙く幅員二十七メートルに拡 張, 湖畔三メートルは垣をつくつて桜樹を植急, 人道十 メートルには二列の街路樹を配してその中間適當の箇所 にベンチをおき，次に車道は十メートル，街路樹によつ て四メートルの人道を設けんとする」という設計案を作 成していた ${ }^{54)}$.「人道」は現在の「歩道」を意味する.

しかし翌年の 8 月に報じられた実施設計の内容によれ ば，湖岸道路の幅員は $27 \mathrm{~m}$ から $19 \mathrm{~m}$ 一変更されたが， 大きく変更されたのがその路線の位置であり, 湖岸沿い から湖畔の宅地背面へと変更された ${ }^{55}$. 同年 12 月の

「湖畔散歩道 工事費の都合で折角の計畫お流れ」と題 する記事によると, 路線の配置変更は総工費 44 万円に 対し埋立地 14,000 坪を宅地として売却し（坪平均 35 円），それを大津市からの寄附金と合わせて工費へ充当 する方針であったが，売却地が湖畔より後退すれば売却 総額が「半減」してしまうため, 事業実施が困難となる ことから変更せざるを得なかった ${ }^{50}$. 滋賀県は湖岸逍遙 道路の実現を断念寸る代わりに, 逍遙道路に代わる施設 として，小公園や休毠施設を設けることを目指したので ある，埋立地の利用方法の方針については，遊郭の移転 は至難であるが「アミユーズメント・センター（歓楽地 帯）に充當して (…) 大津市の一繁華街」とする意向が 報じられている5 5。実際に 1939-40 年に II.1.2 線の道路の 位置がつけ替えが決定されたが，これを審議した第 15 回都市計画滋賀地方委員会では, 街路変更の理由として 「埋立地ノ適切ナル利用习計ルト共二都市ノ発展二備へ ム」といった説明がなされたに過ぎなかった ${ }^{58}$.

\section{(2) 膳所湖岸埋立事業とその設計}

膳所湖岸埋立（中庄町地先-粟津町地先）は，1935 (昭和 10) 年 10 月に知事の免許を得て, 翌 1936年 2 月 5 日の大津市会において可決された。同年 6 月に起工式 が行われ，1942（昭和 17）年 4月に公有水面 5.74ha の埋 立が完成した（図-5）。
大津市会（1936年 2月）での大津市長堀田義次郎によ る説明（第一号議案「都市計画事業執行ノ件」及び第三 号議案「埋立地処分ノ件」）によれば，この埋立工事は 東洋レーヨンと旭ベンベルグ絹絲の両会社の事業にする といら方針で交渉が成立して事業化に至った ${ }^{59}$. 事業が 成立したのは，工費 185,800 円に対し，大津市は両会社 から 116,798 円の寄附金を受け，その代償として埋立地 面積 17,372 坪のうち 6,186 坪を会社に引き渡すという合 意が成立したためである.もう一つ重要な点は, 湖岸埋 立に際して, 東洋レーヨンと旭ベンベルグ絹絲の両会社 が捨て場所に窮している石炭款と, 瀬田川の浚渫土砂を 使用することで合意したことである.

この事業の決定時，大津市は土地の売却益を用いて道 路建設を行うとした. 具体的には道路敷 7,800 坪を差し 引いた残り 3,358 坪を市有地として売却し, その売却費 用については堀田市長が「之を売つて将来道路を立派に 作る積りであります」と, 道路整備費用に充てる旨を述 べていた。この事業は, 県営の大津湖岸埋立とは異なり, 県費の補助の見込みがなかったのである.

本事業については，第六回都市計画滋賀地方委員会 （1936年 4月 9 日開催）において執行年度割が決定され た. 同委員会においては県土木課長兵藤直吉が説明を行 い，事業収支の見込みについては，上述の素案通りに説 明された. 埋立地内の湖岸道路 II.1.3 線についても執行 年度が決定されたが，本路線の街路構成については街路 の両側に歩道を設け，埋立地内の幅員 $19 \mathrm{~m}$ の区間は $2 \mathrm{~m}$ 幅の植樹帯を施した $5 \mathrm{~m}$ 幅の「逍遥道路」とすることと し，観光上においても適切に設計の予定であると説明が なされた ${ }^{60)}$ (図-6) 。湖岸逍遙道路の断面形態は, 設計 図面からも確認できる（図-7, 湖岸逍遙道路 $5 \mathrm{~m}$-車道 $11 \mathrm{~m}$-歩道 $3 \mathrm{~m}$ の幅員構成) .

全国的に見て戦前期においては都市計画事業の執行が 容易には進捗しないなかで，大津市の湖岸埋立事業が進 んだことは特筆すべきである.この要因は土地の売却に よる収入，すなわち都市計画事業財源の確保にあったと いえよう。なお，事業執行を推進した新大津市の初代市 長・堀田義次郎（1933 年-1942 年在任）は, 滋賀県知事 も務めた（1919-1923 年在任）内務官僚であり, 知事時 代には道路改良を推進するなど土木行政に明るかった。 堀田市長が三期の長期にわたり市長を務めたことも, 埋 立事業の執行が進められた要因の一つである.

\section{（3） 戦後の埋立と湖岸道路の建設}

戦前には，湖岸埋立を除く都市計画事業は大きくは進 捗しなかった。 その要因の一つは 1930（昭和 5）年頃か ら日本に波及した恐慌であり，大津市においても遊覧客 が減少し，交通会社や旅館飲食店などが大きな打撃を受 けた. 加えて 1937 (昭和 12）年の日中戦争以降は, 国 


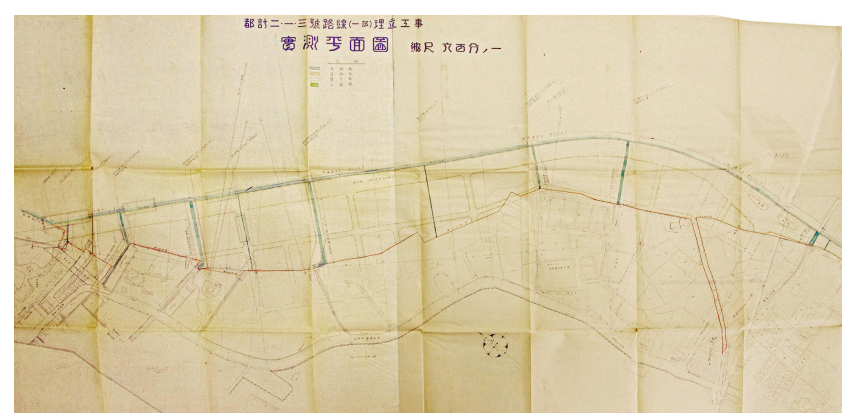

図-5ＩI.1.3 線埋立工事実測図（部分）

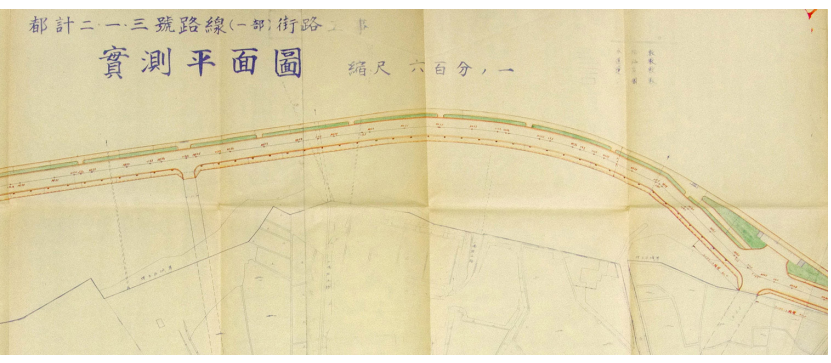

図-6ＩI.1.3線街路実測平面図（部分）

家の事情や社会の情勢は行楽的遊覧を許さない事態とな り，大津市は観光課を中心に，健民運動の枢軸，心身鍛 成の機関として，遊覧都市構想の刷新に努めたが，1941 （昭和 16）年には観光課が廃止されるに至った ${ }^{61) .}$

浜大津-石山間の湖岸道路は戦後に実現した. 浜大津紺屋が関の 800m を湖岸埋立により造成した（1949-1951 年）のを皮切りに，1950（昭和 25）年に大津市は都市 計画による湖岸道路の整備を決定し，翌年から島の関か ら馬場までの 1.3kmを造成し（1951-1957年），さらに馬 場から近江大橋付近まで $1.3 \mathrm{~km}$ を造成（1958-1964年）し た ${ }^{62)}$.

浜大津周辺の湖岸道路に関していえば，戦後に「観光 大津」を掲げた大津市長・佐治誠吉（1949-52 年在任） が，1950年 1 月の段階で「湖岸一体は計画中の埋立と併 行して全市域の湖岸を三十メートル巾に臨湖公園とし, 公園より内側にドライヴエーを設けて $(\cdots)$ 周遊道路と

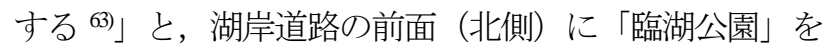
設けることによって，逍遙道路の性格を損なわないもの とする計画案を示していた。 これは戦前の計画思想を引 き継いだものであったといえよう。この浜大津-膳所網 町間の湖岸道路は，1951（昭和 26）年度に工事が着手さ

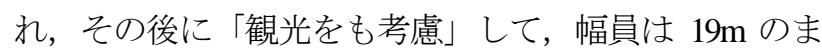
まで遊歩道は $10 \mathrm{~m}$ に拡幅するよう設計変更され ${ }^{64)}$, 1958（昭和 33）年 6 月に開通祝賀式を迎えた。この 2,243m の区間においては，幅 $18 \mathrm{~m}$ の自動車道と幅 $10 \mathrm{~m}$ の遊歩道が備えられ, 桜, 松並木も植えられて整備され たのである ${ }^{65)}$ (図-8 ${ }^{60)}$ ）．

しかし，その後「湖岸道路」の景観は大きく変貌した。 戦前の計画では, 湖岸の風致を考慮し, 造成した埋立地 の北端の湖岸沿いに湖岸道路を建設することとしていた.

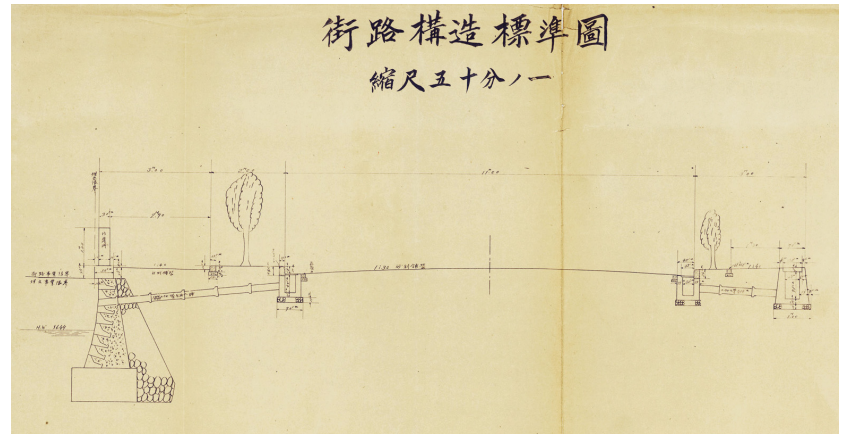

図-7ＩI.1.3 線街路構造標準図（部分）

(図-5-7 : 都市計畫滋賀地方委員會「第六回委員會書類」中, 「大津都市計畫埋立及街路事業決定二関スル件」（1936）所収）

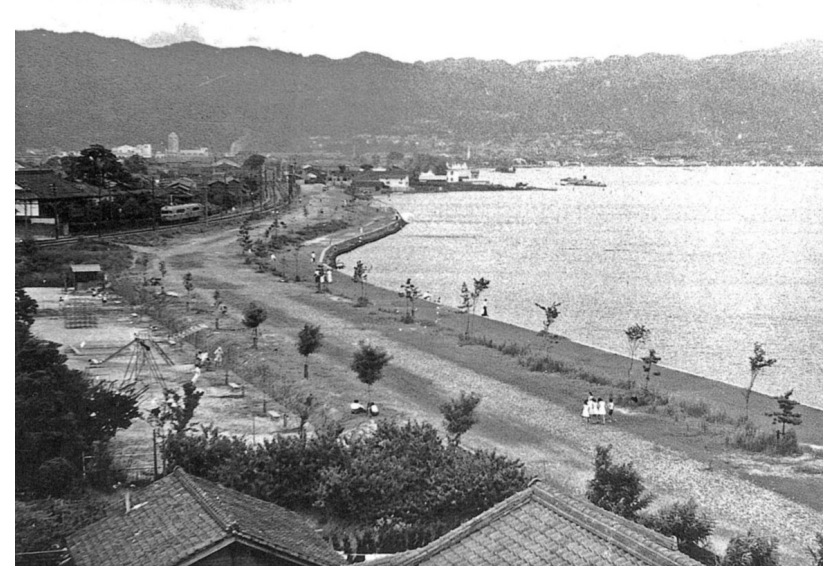

図-8 竣工した湖岸道路（昭和 30 年代前半，大規模埋立以前）

実際にこうして湖岸道路は実現したが，早期の建設が 優先されたために，埋立地を造成するより前に湖岸道路 を建設するに至った. そのため, 湖岸道路の完成後, 具 体的には昭和 34 年度以降に, 湖岸道路の前面（北側） に埋立地造成がなされた. その後, 湖岸側の埋立地に各 種施設の建築物が建てられ，これにより「湖岸道路」は 湖岸に面さなくなり，その名のみを残すこととなったの である．実質的に「湖岸道路」が湖岸に存在したのは昭 和 33 (1958) 年度までのごく僅かの期間に限られた。 そ の後「湖岸道路」は，1965-66 年に膳所公園-御殿ヶ浜間 820m（1966-1966），唐橋前-蛍谷間 800m（1967年）が完 成して全区間の開通をみた。

その後, 浜大津 - 膳所間の埋立地造成が進んだ後も, 水辺にはオープンスペースがほとんどなく, 護岸の大部 分もコンクリートや鋼矢板によるもので親水性や魅力に 乏しかったが，1987 年度から「大津湖岸なぎさ公園」 として新たに湖岸を埋め立てて水辺の整備が進められ, 面積約 30.3ha，延長 $4.8 \mathrm{~km}$ の大規模な湖岸公園がプロム ナードとともに整備されたの。これは戦前から実現が目 指されてきた「逍遙道路」や「湖畔公園」が，三十年以 上の空白期間を経て，より発展した形で実現したもので あると評価できよう。 


\section{8. 結語}

本研究は，戦前の大津における遊覧都市構想の内実と， これに基づき策定された都市計画街路網及び湖岸埋立計 画（1932）の具体的内容とその計画策定意図，およびそ れらの実現過程を明らかにした，各章においては，都市 建設をめぐる理念，実現の手段，関係主体のはたらきに 着目して考察を行った. 本研究の成果を以下に述心゙る.

1920 年代後半以降の大津市では, 国際観光リゾート 地開発運動を背景に，「遊覧都市」の建設が都市計画の 目標として明確に位置づけられた。特に大津市の市町村 合併（1933 年）の際には，新市の方針として遊覧都市 としての発展と遊覧施設の完備を目指寸ことが強く主張 され，市の合併条件のなかにも盛り込まれた．この大津 の遊覧都市構想は，明治末年以降の大津市や滋賀県，民 間会社によって幾度となく構想・出願された湖岸埋立お よび逍遙道路建設構想の考えを引き継いだものであった 1920 年代半ばには，埋立事業の推進において，中井大 津市長と末松滋賀県知事を中心として県市の協力体制が 築かれた．大津においては内務省都市計画滋賀地方委員 会が設けられる以前から，市会や県を中心に目標とする 都市像が構築されており，また湖岸埋立や逍遙道路を中 心とする都市建設の重要性が共有されていた。これらは 政治的あるいは治水上の理由から実現には至らなかった ものの，その内容は後の都市計画案に引き継がれた.

1932（昭和 7）年に決定された都市計画街路網と埋立 計画は，遊覧都市の実現を目的して策定された。街路網 計画は交通問題の解消と遊覧系統の充実があわせて図ら れ, 幹線としての湖岸逍遥道路と, 名勝地間の連絡道路, 水辺の風致的道路の計画を含んだ．湖岸埋立は，地勢に 起因する狭長な既存市街地の改造の困難さ，湖岸の個人 的な占用と衛生と美観上の問題を背景として，これらの 解決と交通の完備, 都市施設の充実を図るとともに, 近 代的遊覽都市に相応しい湖岸空間を実現することが図ら れた．都市計画事業を通じて近代的公共空間の創出が試 みられたのであったが，これらの計画案は，それまでの 大津市の都市建設構想を継承し展開寸るものであった. 都市計画滋賀地方委員会技師として街路網と埋立計画を 策定した塩原三郎は，滋賀県農林技手であった佐藤昌と ともに，新設された大津市観光課の嘱託として，都市計 画事業の範疇を超える総合的な観光施策にも取り組み, 史蹟名勝を活用した公園や遊覧地整備の計画立案を行っ た．湖岸は景色を眺め，腰を落ち着ける場所としての道 路や公園の整備が意図され，そのほか歴史的な松林景観 の再現や，水辺を中心とする遊園地の改良によって，公 共空間の近代化が目指された。

湖岸埋立は，遊覧都市建設上不可欠のものと位置づけ られ，戦前から戦後にかけて実現した。埋立事業の執行
を可能にしたのは公有地の造成とその売却益による事業 収入であった．特に戦前の事業実施期の市長を務めた堀 田は滋賀県の内務部長や知事を務めた土木事業に明るい 内務官僚であり，このことは都市建設事業の遂行を助け た. 遊覧都市の実現のための湖岸埋立ならびに湖岸逍遥 道路整備においては，風致の考慮が図られ，たとえば尾 花川埋立地は湖岸に $13 \mathrm{~m}$ の植樹帯と歩道を設け, 湖畔 の桜に加えて二列並木が設ける設計案が作られていた. 遊覧都市の建設は，戦後も重要な施策とされたが，実際 の事業の経過をみると，膳所では当初の設計思想を継承 して実現したものの，尾花川では埋立地売却による収益 を上げるために湖岸道路は内陸へと移され，戦前の計画 時の趣旨を満たすものとはならなかった，また，浜大津 では道路の早期実現のために埋立予定地の内側に湖岸道 路が建設され，埋立地も公園にする案であったが，諸施 設が築造されることにより湖岸道路の逍遥道路としての 特色は失われた。このように一部の湖岸逍遙道路につい ては，計画策定時に重視された風致を考慮した設計が事 業化の段階で変更され，計画当初の趣旨に反するものと して形づくられた. その後の埋立地造成によっても水辺 は魅力に乏しい状況であったが，1987 年度から湖岸公 園やプロムナードが整備され, 戦前からの逍遥道路・湖 畔公園の考え方が形を変えて実現した.

以上をふまえて近代大津における都市計画の意義につ いて述べる．大津では明治末年以降，湖岸を中心とする 都市建設構想が示され，その理念が広く共有されつつあ ったが，都市計画の適用以前には実現するに至らなかっ た．旧法下の都市計画によって，内務省の都市計画技師 らによる技術的検討の上に都市計画決定として定め，計 画を権威づけ，さらには都市計画事業として執行寸る手 続きが整えられた，すなわち都市計画が湖岸の埋立を伴 う大規模な都市整備の重要な契機となった. さらに, こ の都市計画の推進の原動力となったのが, 国際リゾート 開発地運動を背景と寸る「遊覧都市」という明確な都市 像の確立と，それに基づいた市，県の長期にわたる協働 的推進であり，それを可能にした埋立地売却による事業 財源の捻出であった. 都市計画事業を通じた風致整備も しくは近代的公共空間の創出という都市計画策定当初の 理念は，一部は実現につながらなかったものの, その後 の大津の都市形成，水辺空間形成の重要な基礎となった.

謝辞 : 本研究にあたり, 滋賀県県政史料室には史料の提 供など多大な支援を頂いた。ここに感謝の意を表す。な お，本研究はJSPS科研費23760573の助成を受けたもので ある。

\section{注}

(1) 1930年代の国際観光政策とは，外貨獲得のために鉄道 
省が中心となって進めた日本への外国人旅行客誘致策 であり，国際観光ルートを選定するとともに国内各地 に国際観光ホテルの整備を進めた。琵琶湖ホテルのほ か, 上高地ホテルや雲仙観光ホテルなどが知られる.

（砂本文彦：近代日本の国際リゾートー1930年代の国 際観光ホテルを中心に，青弓社，2008.）

(2) 本研究に先立ち, その内容の一部を講演論文として発 表している。（田中倫希，山口敬太，川崎雅史：昭和 初期の大津市における湖岸埋立と街路網の形成 一遊覧 都市の建設をめぐって一，土木史研究講演集 第31回， pp.25-35，2011)

(3) 本研究の主要な史料である都市計画滋賀地方委員会書 類は，滋賀県県政史料室に所蔵されているものである 同室は2008年6月に開設され，同史料群も同時期に公開 された。筆者らは同室開設直後から史料の収集整理に 努め, 本稿で使用した都市計画図面等については電子 化の協力を行った.

(4)太湖汽船（1882年設立）と湖南汽船（1886年設立）の 両社が琵琶湖遊覧事業を展開したが, 京津電気軌道の 京都三条-浜大津間開通（1912年）後には，大津電車軌 道株式会社も三井寺-浜大津-馬場（膳所）-石山寺間を 開通させ，鉄道と汽船（太湖汽船と湖南汽船）の連絡 を強めて遊覧客の招致に努めた。1925（大正14）年に は，八景めぐり（大津-南郷遊園地-堅田）の定期遊覧 就航が開始された。

(5)管見の限りにおいて，大津市会において都市建設とい う文脈のなかで「遊覧都市」という言葉が用いられる のは，これが最初である。

(6)大津市の都市計画案が紙上に報じられた際には「市制 施行以来三十年間地利的に遊覧都市としての面目を保 ちながら土木政策の恩恵に浴してみない大津市もこれ を機会に近くグレート大津市，遊覧の大津市としての 発展は見るべきものであろう」と期待された。（大阪 朝日新聞滋賀版 1928年12月15日付）

(7)「鉄道御用地植樹二付御願」（1913年9月8日） 北側鉄道線路法地延長百余間について「埋立タル御用 地ノ傍二沿ヒ幅員二間半ノ道路相設候義二付右埋立夕 ル御用地八目下御不用ノ姿卜相成居リ $(\cdots)$ 埋立タル 地八長方形ニシテ大津市湖岸中風景絶勝ノ地ナルガ故 二四時共二公衆ノ娛楽場卜相成申候就テハ右埋立タル 法地八御用ノ相生シ候当会社二於テ松櫻楓柳其他風致 木数十株 Э植栽致 ( $\cdots$, 加えて) 線路間二立入ル 7 防 グ為メ木柵 习設ケ大津市湖岸ノ風致习増進候様致」 (傍線，括弧内筆者)

(8) 西田與三郎：大津信用組合幹事を経て，市議（1910年-) 及同参事会員（1911年-）を経て県議及県参事会員 （1919年-），また市会議長（1919年-）を経て大津市 長（1930-1933年）を務めた。地方自治については熱心 な研究家であり, 県市会を通じて右に出るものはない というほど経理・経済にかけては得意だったという。

(滋賀日出新聞社経済部編 : 大津市人物名鑑, 1936, 滋 賀日出新聞社)

また，戦前の大津市長である中井（在任期間1922-26年） 以降，奥野（同1926-30年），西田，堀田（同1933-42 年）と, いずれも湖岸道路及び埋立計画を熱心な推進 者であった。

(9)本記事は砂本の研究（前掲 近代日本の国際リゾート）
でも取り上げられている.

(10)塩原三郎は1934（昭和9）年6月まで都市計画滋賀地方 委員会技師として任に当たり，その後千葉地方委員会 一転任し，都市計画東京地方委員会技師，華北臨時政 府建設総署, 北海道, 新潟, 愛知, 宮城で都市計画地 方委員会技師を歴任し，建設省を経て，帰郷して前橋 市建設部長や企画室長を歴任した（1955.4-1965.4）.

(塩原三郎 : 都市計画 華北の点線, 塩原三郎, 1971)

（11）「休養地の保存，開発に関して，或は休養地相互の 関係に於て，或は遊覧的交通施設並びに遊楽施設に於 て，或は都市構築上都市美考慮に於て，或は遊覧施設 関係者の協力或は宣伝に於て, 或は地勢気候風土に対 する休養遊楽施設の適応に於て至らざるところ大なり と認むる」（塩原三郎：休養地としての大津及其近郊, 大阪都市協会 : 大大阪 九巻四号, pp.62-67, 1933）

(12)筆者が2010年4月に古書店にて購入したもの．管見で は所蔵している公共図書館や資料館は見当たらない. 本書の第三章「都市計画事業遂行の必要」では，大津 の都市計画は, 一部の工業区域を除いて湖岸遊覧都市 として全国に認められることを目標とし，かつ前提に おいてこれが行われていると明確に述べられている.

\section{参考文献}

1) 京都市市政史編さん委員会 : 京都市政史 第二巻 市政 の展開，京都市，pp.530-537，2012.

2) 大津市：新修大津市史 現代 第六巻，大津市， 1983.

3) 大津市役所編輯 : 大津市史 中巻, 大津市, pp.812-816, 1942.

4) 砂本文彦：近代日本の国際リゾートー1930 年代の国 際観光ホテルを中心に，青弓社，2008.

5) 奈良本辰也編, 大津市著 : 新大津市史下, 大津市, pp.760, 811, 1962.

6) 前掲 新大津市史下，pp.13-20, 750-763.

7) 前掲 新修大津市史現代 第六巻.

8) 大津市歴史博物館編：家族の一世紀，大津市歴史博物 館, 1998.

9) 滋賀県史編さん委員会 : 滋賀県史 昭和編 第二巻 行政 編，滋賀県，1974.

10) 太湖汽船株式會社：太湖汽船の五十年, 太湖汽船, 1937.

11) 大津市会会議録 1927 年 9 月 28 日付, 「本市ヨ都市 計画法施行ノ市トシテ指定方其筋へ申請ノ件」.

12) 朝日新聞滋賀版 1927 年 12 月 16 日付.

13) 滋賀県 : 昭和八年四月大津 - 膳所 - 石山廃置記録, 滋 賀県，1934.

14) 前掲 昭和八年四月大津・膳所 - 石山廃置記録.

15) 朝日新聞滋賀版 1933 年 4 月 1 日付.

16) 滋賀県行政文書「1899-1915 年 大津市并湖南汽船会社経営 埋立一件書類」（明ぬ 58）

17) 鉄道御用地植樹二付御願，1913 年 9 月 8 日付，前掲 滋賀県行政文書「1899-1915 年 大津市并湖南汽船会社経営 埋立一件書類」.

18) 前掲 滋賀県行政文書「1899-1915 年 大津市并湖南汽船会 社経営埋立一件書類」.

19) 中村紅雨編 : 大津市三十年史, 湖国舎, 1928.

20) 続近江史を歩く，京都新聞滋賀版 1984 年 2 月 16 日付.

21) 大津市議会編：大津市議会史 記述編，大津市議会， 
pp.50-51, 1991.

22) 大津市会会議録 1929 年 2 月 14 日付.

23) 大津市公報，第 47 号附録，1929年 3 月 20 日付.

24) 前掲 大津市会会議録 1929年 2 月 14 日.

25) 大津市役所 : 大津市史，大津市，p.76， 1941.

26) 前掲 大津市公報, 1929 年 3 月 20 日付.

27) 朝日新聞滋賀版 1929 年 1 月 16 日付.

28) 前掲 大津市会会議録 1929 年 2 月 14 日.

29) 朝日新聞滋賀版 1929 年 1 月 17 日付.

30) 都市計畫滋賀地方委員會第二回議事録, 1929 年 5 月 28 日付：滋賀県行政文書「都市計画審議会議事録 （旧法）第一回から第三○回」（昭な 183）

31) 大津市観光課 : 大津市観光施設調査報告書, 大津市, 1933.

32) 朝日新聞滋賀版 1931 年 8 月 21 日付.

33) 時事時言, 建築世界 第 24 巻 3 号, 建築世界社, 1930.

34) 街路決定理由書, 都市計畫滋賀地方委員會第三回議事 録：前掲 滋賀県行政文書「都市計画審議会議事録」。

35) 大津都市計畫街路網並埋立設計概要, 1932 : 滋賀県行 政文書「街路並埋立決定ノ件（都市計畫滋賀地方委員會 第三回委員會書類）」（昭な 184）.

36) 前掲 大津都市計画街路網並埋立設計概要, pp.21-39

37) 塩原三郎：大津都市計画埋立に就て, 都市研究会編 : 都市公論 第十六巻第二号, pp.61-70, 1933.

38) 前掲 大津都市計画街路網並埋立設計概要.

39) 前掲 大津都市計画埋立に就て.

40) 都市計画街路標準断面, 1932, 前掲「街路並埋立決定 ノ件（都市計畫滋賀地方委員會第三回委員會書類）」。

41) 滋賀県: 埋立案及理由書, 1932, 前掲「街路並埋立決 定ノ件（都市計畫滋賀地方委員會 第三回委員會書類）」。

42) 塩原三郎 : 都市計画の旅, 塩原三郎, 1981.

43) 前掲 都市計画の旅, pp.8-9.

44) 前掲 大津都市計画街路網並埋立設計概要.

45) 前掲 大津都市計画街路並埋立設計概要.

46) 滋賀県：大津都市計画埋立収支概算帳，1932，前掲 「街路並埋立決定ノ件（都市計畫滋賀地方委員會 第三回
委員會書類)」.

47) 前掲 大津都市計画街路並埋立設計概要.

48) 塩原三郎 : 新大津市と都市重要施設, 都市研究会編 : 都市公論 第十六巻第四号, pp.50-53, 1933.

49) 塩原三郎：休養地としての大津及其近郊, 大阪都市協 会 : 大大阪九巻四号, pp.62-67, 1933.

50) 前掲 大津市観光施設調査報告書.

51) 大津市会会議録 1937 年 3 月 3 日付.

52) 前掲 滋賀県史 昭和編 第二巻行政編, p.608.

53) 前掲 近代日本の国際リゾートー1930 年代の国際観 光ホテルを中心に.

54) 朝日新聞滋賀版 1935 年 4 月 28 日付.

55) 朝日新聞滋賀版 1936 年 8 月 16 日付.

56) 朝日新聞滋賀版 1936 年 12 月 22 日付.

57) 朝日新聞滋賀版 1937 年 4 月 14 日付.

58) 滋賀県行政文書「1942-1943 年 都市計画滋賀地方委員 会書類第十五回都市計画地方委員会」（昭な 193）.

59) 大津市会会議録 1936 年 2 月 5 日, 大津市公報 87 号 附録, 1936 .

60) 都市計畫滋賀地方委員會第六回議事録, 1936 年 4 月 9 日，前掲滋賀県行政文書「都市計画審議会議事録」.

61) 大津市役所編：大津市政の十年，大津市役所，1943.

62) 斎藤喜栄治, 樋口寛 : 湖岸道路一歴史と文化の街大津 一, 日本道路協会: 道路道路 : road engineering \& management review, 521 号, pp.64-69, 1984.

63) 滋賀新聞 1950 年 1 月 4 日付.

64) 第二十三回都市計畫審議會議事録，1953 年 3 月 16 日, 前掲 滋賀県行政文書「都市計画審議会議事録」.

65) 滋賀日日新聞 1958 年 5 月 31 日付, 朝日新聞滋賀地方 版 1958 年 6 月 3 日付.

66) 前掲 家族の一世紀, p.57.

67) 竹川勇 : 『大津湖岸なぎさ公園』について, ランドス ケープ研究, Vol.62, No.4, pp.392-393, 1999.

(2014.9.16 受付)

\title{
TOURISM DEVELOPMENT AND CITY PLANNING IN OTSU THROUGHOUT THE MODERN PERIOD -PLANNING AND IMPLEMENTATION OF LAKE RECLAMATION AND LAKESIDE PROMENADE-
}

\author{
Keita YAMAGUCHI, Michiki TANAKA and Masashi KAWASAKI
}

This study aims to investigate the urban history and thoughts of city planning in Otsu in the 1920-30s, clarifying the concept of "Tourist City" and concrete ideas of road network and lake reclamation plan of Otsu, and its planning process. The summary and achievements of the study are as below. Otsu city and Shiga prefecture attempted to realize lake reclamation and lakeside promenade several times in the 19101920s. Then Otsu city held up a concept of "Tourist City" as a main aim of city planning in the latter half of the 1920s. The plan for the city of Otsu including road network and lake reclamation determined in 1932 was intended to connect tourist sites and build recreational facilities, and improve the scenic beauty of the lakeside. Lake reclamation of Otsu city was realized partially in prewar times by selling municipal reclaimed land, and the lake promenade was constructed before 1960s even though a large part of the promenade lacked its original aims. Otsu city had carried out these infrastructure construction projects by the long-term collaboration with Shiga Prefecture. 